\title{
Periparturient effects of feeding a low dietary cation-anion difference diet on acid-base, calcium, and phosphorus homeostasis and on intravenous glucose tolerance test in high-producing dairy cows
}

\author{
W. Grünberg, ${ }^{* 1}$ S. S. Donkin, $\dagger$ and P. D. Constable‡ \\ *Department of Farm Animal Health, Utrecht University, 3584 CL Utrecht, the Netherlands \\ †Department of Animal Sciences, and \\ ‡Department of Veterinary Clinical Sciences, Purdue University, West Lafayette, IN 47907
}

\begin{abstract}
Feeding rations with low dietary cation-anion difference (DCAD) to dairy cows during late gestation is a common strategy to prevent periparturient hypocalcemia. Although the efficacy of low-DCAD rations in reducing the incidence of clinical hypocalcemia is well documented, potentially deleterious effects have not been explored in detail. The objective of the study presented here was to determine the effect of fully compensated metabolic acidosis on calcium and phosphorus homeostasis, insulin responsiveness, and insulin sensitivity as well as on protein metabolism. Twenty multiparous Holstein-Friesian dairy cows were assigned to 1 of 2 treatment groups and fed a low-DCAD ration (DCAD $=-9 \mathrm{mEq} / 100 \mathrm{~g}$, group $\mathrm{L}$ ) or a control ration (DCAD $=+11 \mathrm{mEq} / 100 \mathrm{~g}$, group $\mathrm{C}$ ) for the last $3 \mathrm{wk}$ before the expected calving date. Blood and urine samples were obtained periodically between $14 \mathrm{~d}$ before to 14 $\mathrm{d}$ after calving. Intravenous glucose tolerance tests and 24-h volumetric urine collection were conducted before calving as well as 7 and $14 \mathrm{~d}$ postpartum. Cows fed the low-DCAD ration had lower urine $\mathrm{pH}$ and higher net acid excretion, but unchanged blood $\mathrm{pH}$ and bicarbonate concentration before calving. Protein-corrected plasma Ca concentration $1 \mathrm{~d}$ postpartum was higher in cows on the low-DCAD diet when compared with control animals. Urinary $\mathrm{Ca}$ and $\mathrm{P}$ excretion was positively associated with urine net acid excretion and negatively associated with urine $\mathrm{pH}$. Whereas metabolic acidosis resulted in a 6-fold increase in urinary $\mathrm{Ca}$ excretion, the effect on renal $\mathrm{P}$ excretion was negligible. A more pronounced decline of plasma protein and globulin concentration in the periparturient period was observed in cows on the low-DCAD diets resulting in significantly lower total protein and globulin concentrations after calving in cows on low-DCAD diets. Intravenous glu-
\end{abstract}

Received April 4, 2010.

Accepted September 20, 2010.

${ }^{1}$ Corresponding author: waltergruenberg@yahoo.com cose tolerance tests conducted before and after calving did not reveal group differences in insulin response or insulin sensitivity. Our results indicate that fully compensated metabolic acidosis increased the Ca flux resulting in increased urinary calcium excretion before calving and increased plasma Ca concentration on the day after calving, whereas the effect on $\mathrm{P}$ homeostasis was unlikely to be clinically relevant. The clinical relevance of the effect of metabolic acidosis on the plasma protein and globulin concentration is unclear but warrants further investigation.

Key words: endocrinology, lactation

\section{INTRODUCTION}

Periparturient hypocalcemia or milk fever is a common condition of dairy cows with an annual incidence of 5 to $8 \%$ (USDA, 2007a). Feeding rations with low DCAD to dairy cows for 2 to 3 wk before calving is used in $27 \%$ of dairy operations and $45 \%$ of dairy cows in the United States to decrease the incidence of periparturient hypocalcemia (USDA, 2007b). The mechanism by which diets with low DCAD prevent clinical hypocalcemia in the periparturient period is not completely understood but appears to be associated with metabolic acidosis and increased $\mathrm{Ca}$ flux due to increased $\mathrm{Ca}$ absorption from the gastrointestinal tract and mobilization of $\mathrm{Ca}$ from bone, which combine to increase Ca excretion in urine (Fredeen et al., 1988; Schonewille et al., 1994; Constable, 1999; Goff and Horst, 2003). The efficacy of low-DCAD rations as a strategy to prevent periparturient hypocalcemia is well documented (Ender et al., 1971; Dishington, 1975; Block, 1984; Oetzel et al., 1988). However, concerns have been raised about the safety of low-DCAD rations in that acidogenic rations decrease DMI in late gestation (Charbonneau et al., 2006; Constable et al., 2009), thereby exacerbating the metabolic effects of negative energy balance in early lactation.

Chronic acidemia due to persistent metabolic acidosis has been associated with several deleterious metabolic 
Table 1. Ingredients and composition of close-up ration of treatment and control group

\begin{tabular}{|c|c|c|}
\hline \multirow[b]{2}{*}{ Item } & \multicolumn{2}{|c|}{ Treatment } \\
\hline & Control & $\begin{array}{c}\text { Low } \\
\text { DCAD }\end{array}$ \\
\hline \multicolumn{3}{|l|}{ Ingredients (\% DM) } \\
\hline Grass hay & 13.9 & 13.9 \\
\hline Corn silage & 39.4 & 39.4 \\
\hline Alfalfa haylage & 6.9 & 6.9 \\
\hline Cottonseed hulls & 6.2 & 6.2 \\
\hline Soybean hulls & 7.14 & 7.14 \\
\hline Ground corn grain & 6.0 & 6.0 \\
\hline Soybean meal & 6.0 & 2.0 \\
\hline Biochlor $^{1}$ & 0.0 & 4.0 \\
\hline ProvAAI Basic $^{2}$ & 0.6 & 0.6 \\
\hline Calcium carbonate & 0.5 & 0.5 \\
\hline Calcium phosphate & 0.2 & 0.2 \\
\hline Magnesium oxide & 0.1 & 0.1 \\
\hline Sodium chloride & 0.5 & 0.5 \\
\hline $\mathrm{TMV}^{3}$ & 0.9 & 0.9 \\
\hline Yeast & 0.3 & 0.3 \\
\hline Magnesium sulfate & 0.2 & 0.2 \\
\hline Vitamin E, 20,000 IU & 0.2 & 0.2 \\
\hline Rumensin $80^{4}$ & 0.2 & 0.2 \\
\hline Omnigen $\mathrm{AF}^{5}$ & 0.2 & 0.2 \\
\hline Megalac $^{1}$ & 0.5 & 0.5 \\
\hline \multicolumn{3}{|l|}{ Chemical analysis } \\
\hline DM (\% as fed $)$ & 50.7 & 50.7 \\
\hline $\mathrm{NE}_{\mathrm{L}}(\mathrm{Mcal} / \mathrm{kg})$ & 1.43 & 1.42 \\
\hline $\operatorname{NDF}(\%)$ & 40.1 & 40.5 \\
\hline NFC (\%) & 34.6 & 34.3 \\
\hline Starch $(\%)$ & 19.8 & 20.1 \\
\hline $\mathrm{CP}(\%)$ & 15.3 & 15.1 \\
\hline Lignin $(\%)$ & 4.2 & 4.4 \\
\hline $\mathrm{Ca}(\%)$ & 0.97 & 0.98 \\
\hline $\mathrm{K}(\%)$ & 1.21 & 1.20 \\
\hline $\mathrm{Cl}(\%)$ & 0.30 & 0.98 \\
\hline $\mathrm{P}(\%)$ & 0.33 & 0.33 \\
\hline $\operatorname{Mg}(\%)$ & 0.38 & 0.38 \\
\hline $\mathrm{S}(\%)$ & 0.25 & 0.37 \\
\hline $\mathrm{Na}(\%)$ & 0.08 & 0.16 \\
\hline DCAD & +15 & -13 \\
\hline
\end{tabular}

${ }^{1}$ Arm and Hammer Animal Nutrition, Princeton, NJ.

${ }^{2}$ Venture Milling, Salisbury, MD.

${ }^{3}$ Trace mineral pack; KNS Inc., Lawrenceburg, KY.

${ }^{4}$ Rumensin 80; Elanco Animal Health, Indianapolis, IN.

${ }^{5}$ Omnigen AF; Phibro Animal Health Corp., Ridgefield Park, NJ.

effects in humans and domestic animals, including decreased feed intake, decreased insulin responsiveness and insulin sensitivity, as well as increased protein catabolism (MacKler et al., 1951; Ballmer and Imoberdorf, 1995; Bigner et al., 1996; Hu et al., 2007). To our knowledge, some of the deleterious effects of sustained acidemia and metabolic acidosis have been minimally investigated in dairy cows fed rations with a low DCAD in late gestation, and it is not clear whether fully compensated metabolic acidosis (i.e., $\mathrm{pH}$ remaining within the reference range) is associated with deleterious effects in dairy cattle. Accordingly, the purpose of the study reported here was to determine the effect of fully compensated metabolic acidosis on feed intake, acid- base balance, calcium and phosphorus homeostasis, insulin responsiveness, and insulin sensitivity as assessed by the intravenous glucose tolerance test, and plasma concentrations of different protein fractions in high-yielding dairy cows.

\section{MATERIALS AND METHODS}

All methods were approved by the Purdue University Institutional Animal Care and Use Committee.

\section{Animals, Housing, and Feeding}

Twenty pregnant, nonlactating multiparous HolsteinFriesian cows were dried off 8 wk before the predicted calving date. Cows were moved from a dry lot into a temperature-controlled building 25 to $21 \mathrm{~d}$ before the predicted calving date and housed in individual tiestalls bedded with rubber mats covered with sawdust. Cows were healthy on the basis of a physical examination. Feed was offered as TMR based on grass hay, alfalfa haylage, and corn silage formulated to meet the requirements of dry cows based on the recommendations of the National Research Council (NRC, 2001, Table 1). Cows were acclimatized to their diet for 7 to $11 \mathrm{~d}$ before being studied from $14 \mathrm{~d}$ before the anticipated calving date to $14 \mathrm{~d}$ after calving.

Cows were randomly assigned to 1 of 2 groups fed rations with different DCAD from at least $21 \mathrm{~d}$ before the predicted calving date until calving. Cows assigned to the low-DCAD (L) group were fed a balanced, close-up, dry-cow ration to which a commercial chlorine-based anionic salt mixture (Biochlor, Arm and Hammer Animal Nutrition, Princeton, NJ; Table 1) was added to obtain a target DCAD of $-12 \mathrm{mEq} / 100 \mathrm{~g}$ of DM, where $\operatorname{DCAD}($ in $\mathrm{mEq} / 100 \mathrm{~g})=\left(\left[\mathrm{Na}^{+}\right]+\left[\mathrm{K}^{+}\right]\right)-\left(\left[\mathrm{Cl}^{-}\right]+\left[\mathrm{S}^{2-}\right]\right)$ (Lean et al., 2006). Cows assigned to the control (C) group received a similar ration to which an equivalent mass of soybean meal was added instead of the anionic salt mixture to obtain a target DCAD of approximately $+15 \mathrm{mEq} / 100 \mathrm{~g}$ of DM. A DCAD of $+15 \mathrm{mEq} / 100 \mathrm{~g}$ was chosen for the control ration as this value could be easily obtained when formulating a balanced dry-cow ration using feed components with a low $\mathrm{K}$ concentration without further supplementation with anionic salts (Lean et al., 2006; Ramos-Nieves et al., 2009).

After calving, cows in both groups were fed the same balanced TMR that met the requirements of early lactating cows as recommended by the National Research Council (NRC, 2001). This ration was based on corn silage, alfalfa haylage, and high-moisture corn (CP, $17.3 \%$; ADF, $20.1 \%$; NDF, $30.2 \%$; Ca, $0.97 \%$; P, 0.37\%; $\mathrm{Mg}, 0.34 \%$; K, $1.42 \%$ in DM with an energy density of 1.56 MCal $/ \mathrm{kg}$ of $\mathrm{NE}_{\mathrm{L}}$ ). Cows were milked twice daily 
after calving between 0530 and 0800 and between 1900 and 2000 in a milking parlor with the exception of the evenings of $d 7$ and $d 14$ postpartum where cows were milked in the tiestalls to allow for volumetric urine collection as described below. Milk weights were recorded for every milking.

Feed samples were obtained twice weekly from the feed bunk for each group immediately after mixing and were analyzed for $\mathrm{Na}, \mathrm{K}, \mathrm{S}$ (nitric acid digestion), and $\mathrm{Cl}$ (potentiometry with ion selective electrode) content to calculate the DCAD as described previously (AgSource, Bonduel, WI). Dry matter was determined by atmospheric oven drying at $100^{\circ} \mathrm{C}$ to constant weight.

Cows were fed once daily between 0800 and $1000 \mathrm{~h}$. Amounts of TMR fed and refused were recorded daily during the whole study period. Cows that showed signs of preparation for parturition were moved to individual box stalls to calve. Dam and calf were separated within a few hours of calving and cows were returned to tie stalls by d 5 postpartum. Cows were weighed using a calibrated digital large animal scale in the evening before each intravenous glucose tolerance test (IVGTT).

\section{Experimental Study}

Cows in both groups entered the study period on $\mathrm{d}$ -14 relative to the predicted calving date following at least $7 \mathrm{~d}$ of acclimatization. Blood samples were obtained from the jugular vein on $\mathrm{d}-14,-9,-5$, and -3 relative to expected calving as well as on $\mathrm{d} 1,3,5,7$, and 14 postpartum between 0600 and 0900 and before the morning feeding. All blood samples were obtained by venipuncture with the exception of $\mathrm{d}-5,-3,7$, and 14 where blood was obtained from a jugular venous catheter used for the IVGTT described in the following section. Blood for blood gas analysis was collected anaerobically into prechilled, heparinized $3-\mathrm{mL}$ plastic syringes to measure blood gas tensions and $\mathrm{pH}$. Collected samples were placed on ice and analyzed within 30 min using an automated blood gas analyzer (CibaCorning 248, Bayer Diagnostics, Tarrytown, NY). Rectal temperature was measured at the same time as blood sampling for blood gas analysis. Blood for plasma biochemical analysis was collected into prechilled evacuated tubes containing sodium heparin. Tubes were immediately placed on ice, centrifuged within $30 \mathrm{~min}$ at $1,000 \times g$ for $15 \mathrm{~min}$ at room temperature, and the plasma harvested and stored at $-21^{\circ} \mathrm{C}$ until analyzed as described under "Plasma Biochemical Analysis."

Urine was collected by perineal stimulation within 1 $\mathrm{h}$ of blood collection. If urine collection was successful, samples of spontaneously voided urine were collected in $15-\mathrm{mL}$ vials that were completely filled with urine and immediately closed to minimize exposure to air.
Samples were then placed in a water bath at $37^{\circ} \mathrm{C}$ and the urine $\mathrm{pH}$ measured within $15 \mathrm{~min}$ of collection. Thereafter urine samples were stored at $-21^{\circ} \mathrm{C}$ until further analyzed as described under "Urine Biochemical Analysis."

\section{Intravenous Glucose Tolerance Test}

All cows underwent four 24-h urine collection episodes, of which 3 were combined with an IVGTT and 1 was combined with a sham-IVGTT. From each group, 6 cows were selected at random; blood and urine samples obtained during the 3 IVGTT as well as the sham IVGTT were analyzed as described below. The purpose of the sham-IVGTT was to serve as a control treatment to the IVGTT to determine the effect of parenteral dextrose infusion on renal electrolyte excretion. At least $12 \mathrm{~h}$ before each IVGTT or sham-IVGTT a 16-gauge, 83-mm catheter (Angiocath, Becton Dickinson, Franklin Lakes, NJ) was placed into the left or right jugular vein approximately $10 \mathrm{~cm}$ below the mandible and an extension set attached for blood collection. A 14-g, 83 $\mathrm{mm}$ catheter (Angiocath, Becton Dickinson) was placed approximately $15 \mathrm{~cm}$ below the 16-g catheter and an extension set attached for IV dextrose administration. Both extension sets were filled with heparinized saline (40 IU of sodium heparin $/ \mathrm{mL}$ of $0.9 \% \mathrm{NaCl}$ ) and sealed with injection caps, and the catheters were secured to the skin. Approximately $1 \mathrm{~h}$ before the start of each IVGTT or sham-IVGTT, a Foley catheter (28 French, $30-\mathrm{mL}$ balloon) was placed aseptically in the bladder and fixed in position by inflating the balloon with sterile saline. Tubing was attached to the Foley catheter and routed to a $4-\mathrm{L}$ collection jar containing mineral oil for anaerobic urine collection.

During each IVGTT, cows received an intravenous bolus infusion of $500 \mathrm{~mL}$ of $50 \%$ dextrose solution (sterile $50 \%$ dextrose solution, Baxter Co., Columbus $\mathrm{OH})$, approximating a dextrose dose of 0.3 to $0.4 \mathrm{~g} /$ $\mathrm{kg}$ of BW, through the preplaced $14-\mathrm{g}$ catheter at 55 to $100 \mathrm{~mL} / \mathrm{min}$. Periodic blood samples were obtained beginning immediately before the start of infusion over $24 \mathrm{~h}$. For the sham-IVGTT, cows were not infused but instrumented and sampled in a manner similar to that for IVGTT. One IVGTT and 1 sham-IVGTT were performed 5 and $3 \mathrm{~d}$ before the predicted calving date in randomized order with the start of the IVGTT $48 \mathrm{~h}$ apart. The remaining 2 IVGTT were performed on $\mathrm{d} 7$ and 14 postpartum

Blood was collected from the 16-gauge catheter immediately before beginning the dextrose infusion and $10,20,30,45,60,90,120,240,360,480,720,960$, 1,200 and 1,440 min after the onset of infusion. At each sampling time, the catheter was flushed with $3 \mathrm{~mL}$ of 
heparinized saline (40 IU of sodium heparin $/ \mathrm{mL}$ of $0.9 \% \mathrm{NaCl}$ ) and $5 \mathrm{~mL}$ of blood was withdrawn through the catheter. Additional blood was then aspirated via syringe and immediately transferred to prechilled $\mathrm{Na}$ heparin tubes. After obtaining the blood sample, the 5 $\mathrm{mL}$ of blood withdrawn before sample collection were reinjected and the catheter was flushed with $10 \mathrm{~mL}$ of heparinized $0.9 \% \mathrm{NaCl}$ solution. Blood collection tubes were placed on ice immediately after collection and centrifuged within $30 \mathrm{~min}$ at $1,000 \times g$ for $15 \mathrm{~min}$. Harvested plasma was stored at $-80^{\circ} \mathrm{C}$ (for determination of immunoreactive insulin concentration) and at $-21^{\circ} \mathrm{C}$ (for all other serum biochemical parameters) until analyzed.

Urine was collected from the start of the IVGTT at 2-h intervals for the first $4 \mathrm{~h}$ and thereafter at 4 -h intervals for a total duration of $24 \mathrm{~h}$. The bladder was emptied before the start of the IVGTT by manipulating the Foley catheter and thereby stimulating urination. At each sampling time, the total volume of urine was determined and a urine sample was obtained anaerobically from the collection jar. The sample was then transferred into two 5 -mL vials that were completely filled and immediately capped to minimize exposure to air. Urine samples were placed in a water bath at $37^{\circ} \mathrm{C}$ and the $\mathrm{pH}$ was measured within $15 \mathrm{~min}$ before the sample was stored at $-21^{\circ} \mathrm{C}$ until analyzed.

\section{Acid-Base Homeostasis}

Measured values for blood $\mathrm{pH}, \mathrm{Pco}_{2}$, and $\mathrm{Po}_{2}$ were corrected for rectal temperature using standard equations (Burnett et al., 1995). Anion gap (AG; mEq/L) was calculated from the calculated value for $\left[\mathrm{HCO}_{3}{ }^{-}\right]$ (Constable, 1999) as $\mathrm{AG}=([\mathrm{Na}]+[\mathrm{K}])-([\mathrm{Cl}]+$ $\left.\left[\mathrm{HCO}_{3}{ }^{-}\right]\right)$. Strong ion gap (SIGtp; in $\mathrm{mEq} / \mathrm{l}$ ) was calculated as (Constable et al., 2005) SIGtp $=$ [total protein] $\times\left[3.43 /\left(1+10^{7.08-\mathrm{pH}}\right)\right]-\mathrm{AG}$, where [total protein] was measured in grams per deciliter.

Urinary net acid excretion (NAE) and ammonium concentration were determined by titration as described elsewhere (Chan, 1972; Constable, 2007; Constable et al., 2009). Briefly, previously frozen urine was thawed at room temperature, acidified by addition of a fixed volume of $1 \mathrm{~N} \mathrm{HCl}$, and heated to a slow boil for at least 2 min to expel $\mathrm{CO}_{2}$. Urine was then back-titrated with $0.1 \mathrm{~N} \mathrm{NaOH}$ to the $\mathrm{pH}$ of 7.4. Eight percent formaldehyde was then added and the volume of $0.1 \mathrm{NaOH}$ needed to back-titrate the urine sample to a $\mathrm{pH}$ of 7.4 was determined.

\section{Plasma Biochemical Analysis}

Plasma concentrations of inorganic phosphate $(\mathrm{Pi}$, ammonium molybdate), total $\mathrm{Ca}$ (cresolphthalein), $\mathrm{Mg}$ (arsenazo dye binding), albumin (bromocresol green), total protein (TP, biuret), creatinine (picric acid), NEFA (ACS-ACOD method), BHBA (3-hydroxybutyrate dehydrogenase), and glucose (hexokinase) were determined spectrophotometrically (Hitachi 911, Roche Diagnostics, Basel, Switzerland). Plasma concentrations of $\mathrm{Na}, \mathrm{K}$, and $\mathrm{Cl}$ were determined using ion-selective electrodes (Hitachi 911). Although it may have been preferable to have measured ionized $\mathrm{Ca}$ concentration instead of total Ca concentration, $85 \%$ of the variation in ionized Ca concentration in dairy cattle can be explained by variation in the total $\mathrm{Ca}$ concentration (Blum et al., 1972), with the remainder of the variation most likely due to changes in plasma total protein concentration. Plasma Ca concentration was therefore corrected for the plasma TP concentration using an equation validated for lactating dairy cattle (Seifi et al., 2005): $\mathrm{Ca}_{\text {corr }}=[(\mathrm{Ca} \times 0.2495)-(0.015 \times \mathrm{TP} \times$ 10) + 1.2]/0.2495, where $\mathrm{Ca}$ is the plasma total $\mathrm{Ca}$ concentration in milligrams per deciliter and TP is in grams per deciliter. Plasma globulin concentration was calculated as the difference between plasma TP and albumin concentrations.

\section{Analysis of Intravenous Glucose Tolerance Test}

The glucose-concentration time curve after IV administration of $50 \%$ dextrose was modeled as an exponential decline with nonzero asymptote such that [glucose] = $\left(\mathrm{A}_{\mathrm{o}}-\mathrm{A}_{\text {asym }}\right) \times \mathrm{e}^{-\mathrm{k} t}+\mathrm{A}_{\text {asym }}$, with $t=$ time after the start of intravenous glucose administration; $\mathrm{k}=$ elimination rate constant for glucose; $\mathrm{A}_{\mathrm{o}}=$ the extrapolated plasma glucose concentration assuming instantaneous mixing when $t=0 ; \mathrm{A}_{\text {asym }}=$ asymptotic plasma glucose concentration when time $\gg 0$ min. The modeled curve was used to calculate the plasma half life $\left(\mathbf{T}_{50}\right)$ for glucose such that $T_{50}=\ln (2) / \mathrm{k}$. The apparent volume of distribution for glucose $\left(\mathbf{V}_{\mathrm{d}}\right)$ in liters was calculated from the modeled curve for each IVGTT by dividing the amount of glucose infused $(250 \mathrm{~g})$ by the difference between $A_{\circ}$ and $A_{\text {asym }}$ (in $\mathrm{mg} / \mathrm{dL}$ ) using the equation $\mathrm{V}_{\mathrm{d}}=(250$ $\times 1,000) /\left[\left(\mathrm{A}_{\mathrm{o}}-\mathrm{A}_{\text {asym }}\right) \times 10\right]$. The apparent volume of distribution for glucose was calculated to provide an estimate for the extracellular fluid volume because $V_{d}$ should reflect the instantaneous distribution volume for glucose and thereby assist in interpretations of changes in TP and albumin over time.

An aliquot of plasma was assayed for immunoreactive insulin (IRI) using a radioimmunoassay (insulin, Diagnostic Systems Laboratories, Inc., Webster TX). Inter- and intraassay coefficients of variation for IRI were 10 and $7 \%$. The IRI-concentration time curve after IV administration of $50 \%$ dextrose was modeled for every IVGTT as an exponential decline with nonzero 
asymptote such that $[$ IRI $]=\left(\mathrm{I}_{\mathrm{o}}-\mathrm{I}_{\text {asym }}\right) \times \mathrm{e}^{-\mathrm{k} t}+\mathrm{I}_{\text {asym }}$, with $t=$ time after the start of intravenous glucose administration; $\mathrm{k}=$ elimination rate constant for IRI; $\mathrm{I}_{\mathrm{o}}$ $=$ the extrapolated plasma IRI concentration assuming instantaneous mixing when $t=0 ; \mathrm{I}_{\text {asym }}=$ asymptotic plasma IRI concentration when time $\gg 0$ min.

Insulin responsiveness (insulin response to glucose) was evaluated by calculating the peak plasma [IRI], the increment in plasma [IRI] for each IVGTT by subtracting the time $=0 \mathrm{~min}$ (basal) $[\mathrm{IRI}]$ from the peak plasma [IRI], by calculating the area under the plasma [IRI] curve from 0 to $90 \mathrm{~min}$ after the start of the dextrose infusion $\left(\mathrm{AUC}_{\mathrm{IRI}-90}\right)$ and by calculating the ratio of baseline plasma [IRI] to baseline plasma [glucose] (I/G ratio, Muniyappa et al., 2008).

Insulin sensitivity (tissue responsiveness to insulin) was evaluated by calculating the reciprocal of plasma [IRI] $(1 /[\mathrm{IRI}])$ and the glucose to IRI ratio ([glucose $(\mathrm{mg} / \mathrm{dL})] /[\mathrm{IRI}(\mu \mathrm{U} / \mathrm{mL})]$ from the basal plasma [glucose] and [IRI] values obtained before the IVGTT. Insulin sensitivity also was evaluated by calculating the quantitative insulin sensitivity check index (QUICKI) and the revised quantitative insulin sensitivity check index (RQUICKI) which are empirically derived mathematical transformations of basal [glucose], [IRI], and $[\mathrm{NEFA}]$ such that QUICKI $=1 /\left\{\log _{10}\right.$ (basal [IRI]) $+\log _{10}$ (basal [glucose] $\left.)\right\}$ and RQUICKI $=1 /\left\{\log _{10}\right.$ (basal $[$ IRI $])+\log _{10}$ (basal [glucose] $)+\log _{10}$ (basal [NEFA] with [IRI], [glucose], and [NEFA] being measured in $\mu \mathrm{U} / \mathrm{mL}, \mathrm{mg} / \mathrm{dL}$, and $\mathrm{mmol} / \mathrm{L}$ respectively (Katz et al., 2000, Perseghin et al., 2001, Muniyappa et al., 2008). Values for 1/[IRI] and QUICKI provide simple, robust, and accurate indirect methods for evaluating insulin sensitivity (Muniyappa et al., 2008) and RQUICKI is hypothesized to provide an index of insulin sensitivity in dairy cows (Holtenius and Holtenius, 2007).

Insulin sensitivity was also evaluated by examining the plasma phosphorus concentration-time relationship during the IVGTT. Insulin induces a compartmental shift of $\mathrm{Pi}$ into cells of insulin responsive tissue in cattle as in other species (Knochel, 1977; Grünberg et al., 2006), presumably by upregulating the $\mathrm{Na} / \mathrm{Pi}$ co-transporter gene expression (Li et al., 1996). A change in insulin sensitivity might therefore be associated with a change in the plasma [Pi]-time relationship. The maximal decrease in plasma $[\mathrm{Pi}]$ was calculated by subtracting the lowest $[\mathrm{Pi}]$ measured within $2 \mathrm{~h}$ after dextrose infusion from the baseline plasma $[\mathrm{Pi}]$. The area under the plasma glucose concentration curve $\left(\mathrm{AUC}_{\mathrm{Gluc}-120}\right)$ and the area under the plasma $\mathrm{Pi}$ concentration curve $\left(\mathrm{AUC}_{\mathrm{PI}-120}\right)$ from 0 to $120 \mathrm{~min}$ after the start of dextrose infusion were calculated using the trapezoidal rule.

\section{Urine Biochemical Analysis}

Urine $\mathrm{pH}$ was measured immediately after collection using a glass electrode with a rapid response (M3 internal reference glass $\mathrm{pH}$ electrode, Medical Instruments Corp., Solothurn, Switzerland). Stored urine samples were thawed at room temperature and vortexed for $10 \mathrm{~s}$ immediately before biochemical analysis. Urine concentrations of $\mathrm{P}, \mathrm{Ca}, \mathrm{Na}, \mathrm{K}, \mathrm{Mg}$, creatinine, and glucose were determined as described for plasma using appropriate dilutions. Urine $\mathrm{Cl}$ concentration was determined spectrophotometrically (mercuric nitrate) using a commercial test kit (QuantiChrom chloride assay kit, Bioassay Systems, Hayward, CA). Total renal excretion was calculated for $\mathrm{Na}, \mathrm{K}, \mathrm{Ca}, \mathrm{P}, \mathrm{Cl}, \mathrm{Mg}$, and glucose by multiplying urine concentrations by the volume of urine produced per collection time interval. The total amount of glucose excreted in urine in the $12 \mathrm{~h}$ following the dextrose administration was calculated by adding the amounts of glucose excreted in urine determined for each collection interval.

\section{Statistical Analysis}

Data are expressed as mean \pm standard deviation or as geometric mean and range. A $P<0.05$ was considered significant. Values were log-transformed when necessary to achieve a normal distribution. Repeated measures ANOVA was used to detect differences in measured parameters between treatment groups and over time using PROC MIXED (SAS 9.1, SAS Inst. Inc., Cary, NC). Terms in the used model were treatment, time and the interaction of treatment and time. Bonferroni-adjusted $P$-values were used to assess differences within and between treatment groups whenever the $F$-test was significant. The mean actual day before calving was calculated for every sampling time point before calving that was scheduled relative to the predicted calving. A Student's $t$-test was conducted to compare differences in sampling times relative to actual calving between groups.

The associations between several determined parameters and measured urine $\mathrm{pH}$ and NAE, as well as the associations between plasma TP, albumin, and globulin concentrations and the $\mathrm{V}_{\mathrm{d}}$ for glucose were tested using multivariate linear regression analysis. This analysis used dummy variable coding for each cow, which accounted for between-cow variability, thereby increasing the precision with which slope and intercept coefficients for the regression line could be estimated (Glantz and Slinker, 1990). This analytical approach enforces a uniform slope but different intercept value for each cow; 


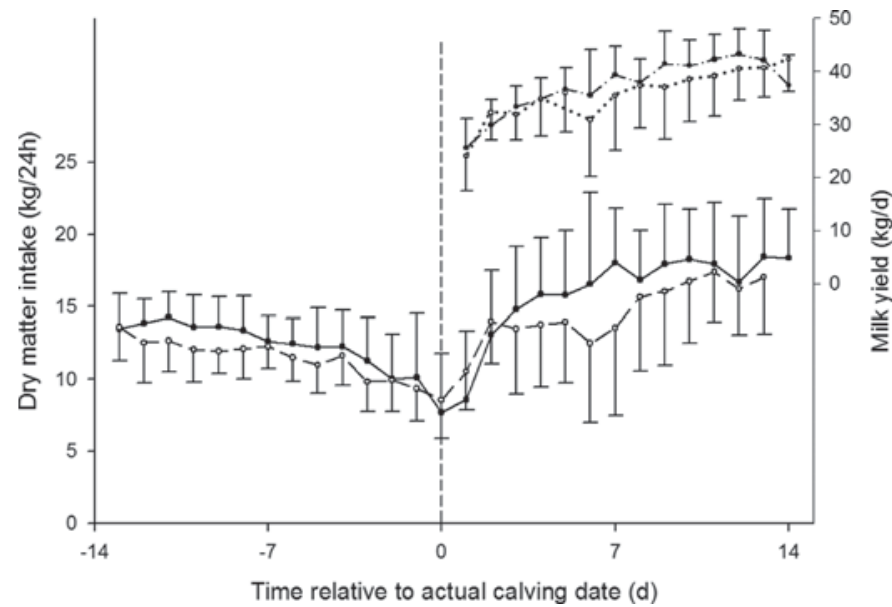

Figure 1. Mean \pm SD daily DMI (lower curves) in group C (closed circles, solid line) and group L (open circles, dashed line) and average milk yields (uppr curves) in group $\mathrm{C}$ (closed circles, dashed-dotted line) and group L (open circles, dotted line) during the study period. The vertical dashed line marks parturition. Twenty multiparous Holstein-Friesian dairy cows were assigned to 1 of 2 treatment groups and fed a low-DCAD ration $(\mathrm{DCAD}=-9 \mathrm{mEq} / 100 \mathrm{~g}$, group $\mathrm{L})$ or a control ration $(\mathrm{DCAD}=+11 \mathrm{mEq} / 100 \mathrm{~g}$, group $\mathrm{C}$ ) for the last $3 \mathrm{wk}$ before the expected calving date.

this approach is appropriate whenever the slopes are similar as in this study. Dummy variables $\left(\mathrm{C}_{1}\right.$ to $\left.\mathrm{C}_{\mathrm{n}}\right)$ were defined as follows: $\mathrm{C}_{1}=1$ if cow $\mathrm{i}(\mathrm{i}<\mathrm{n}),-1$ if cow $=\mathrm{n}$, and 0 otherwise. A statistical software package was used for analysis (SAS 9.1, SAS Inst., Inc.).

\section{RESULTS}

\section{Animals, Feed Intake, and Milk Production}

The mean body weight of cows $6 \mathrm{~d}$ antepartum was $761 \pm 51 \mathrm{~kg}$ in group C and $779 \pm 62 \mathrm{~kg}$ in group L. Six days postpartum, cows in group $\mathrm{C}$ weighed $670 \pm$ $62 \mathrm{~kg}$, and cows in group L weighed $675 \pm 61 \mathrm{~kg}$. The average age was $5.1 \pm 1.5 \mathrm{yr}$ and $4.5 \pm 1.2 \mathrm{yr}$ in groups $\mathrm{C}$ and L, respectively. Differences between groups in BW or age were not significant. Cows on trial received the experimental dry cow ration for $23 \pm 3 \mathrm{~d}$ in group $\mathrm{C}$ and for $24 \pm 4 \mathrm{~d}$ in group $\mathrm{L}$. The time to calving was underestimated by $2 \pm 3 \mathrm{~d}$ in group $\mathrm{C}$ and $3 \pm 4 \mathrm{~d}$ in group L, therefore blood and samples obtained 14, 9, 5 and $3 \mathrm{~d}$ before predicted calving were equivalent to $-16 \pm 3,-12 \pm 3,-7 \pm 3$, and $-5 \pm 3 \mathrm{~d}$ relative to the actual calving time in group $\mathrm{C}$ and $-17 \pm 4,-12$ $\pm 4,-8 \pm 4$, and $-6 \pm 4 \mathrm{~d}$ in group L, respectively. The difference between groups was not significant. The mean DCAD of the ration fed was $-8.7 \pm 2.8 \mathrm{mEq} / 100$ $\mathrm{g}$ in group $\mathrm{L}$ (target was $-12 \mathrm{mEq} / \mathrm{L}$ ) and $+11.3 \pm 2.1$ $\mathrm{mEq} / 100 \mathrm{~g}$ in group $\mathrm{C}$ (target was $+15 \mathrm{mEq} / \mathrm{L})$.
All 20 cows completed the study. One cow in group $\mathrm{C}$ developed pneumonia shortly after calving and was treated with antimicrobial agents and a nonsteroidal antiinflammatory drug. Data obtained from this cow after calving were excluded from statistical analysis. One cow in group L was diagnosed with a left displaced abomasum $8 \mathrm{~d}$ postpartum but recovered uneventfully after surgery. Data obtained from the IVGTT performed on $\mathrm{d} 7$ postpartum of this cow were not included in the statistical analysis. Clinical cases of periparturient hypocalcemia were not observed in either group.

Feed intakes and milk yields did not differ between groups but were numerically lower in group L (Figure $1)$.

\section{Acid-Base Homeostasis}

No treatment effects were observed on blood $\mathrm{pH}$, $\mathrm{pCO}_{2}, \mathrm{pO}_{2}$, base excess $(\mathrm{BE})$, or $\left[\mathrm{HCO}_{3}{ }^{-}\right]$(Table 2). A decline in the $\mathrm{BE}$ and $\mathrm{HCO}_{3}{ }^{-}$between $\mathrm{d}-14$ and 1 d postpartum was observed in both groups but was statistically significant only in group C. Base excess and $\mathrm{HCO}_{3}{ }^{-}$increased in both groups after calving by d 5 postpartum, whereas only a numerical increase of the blood $\mathrm{pH}$ was noticed during the same time period. The AG ranged between $15.9 \pm 3.0 \mathrm{mEq} / \mathrm{L}$ and $18.7 \pm$ $3.4 \mathrm{mEq} / \mathrm{L}$ antepartum and between $16.8 \pm 2.7 \mathrm{mEq} / \mathrm{L}$ and $18.6 \pm 1.8 \mathrm{mEq} / \mathrm{L}$ postpartum in group C. In group $\mathrm{L}$, mean values for the different sampling times ranged from $15.6 \pm 1.6 \mathrm{mEq} / \mathrm{L}$ and $17.6 \pm 3.7 \mathrm{mEq} / \mathrm{L}$ antepartum and $16.4 \pm 3.0$ and $19.8 \pm 7.9 \mathrm{mEq} / \mathrm{L}$ postpartum Neither group nor time effects on AG were significant. The SIGtp ranged between $-2.4 \pm 3.2$ and $+1.7 \pm 3.3$ $\mathrm{mEq} / \mathrm{L}$ in group $\mathrm{C}$ and between $-4.2 \pm 4.4$ and $0.2 \pm$ $3.8 \mathrm{mEq} / \mathrm{L}$ in group L. Values were numerically lower in group $\mathrm{L}$ than in group $\mathrm{C}$, but neither group nor time effects were significant.

Despite the lack of change in blood gas values, a metabolic acidosis was present in group $\mathrm{L}$ as indicated by a higher mean urinary NAE and lower urine $\mathrm{pH}$ than in group $\mathrm{C}$ from $\mathrm{d}-14$ to $\mathrm{d}-3$ relative to calving (Figure 2). Considerable cow-to-cow variation was observed in urine $\mathrm{pH}$ in group $\mathrm{L}$ before calving; in contrast, variability in urinary NAE was similar in both groups. After parturition, the mean urinary $\mathrm{pH}$ in group L increased immediately (by d 1 postpartum) to approximate the values in group C. Differences in urine $\mathrm{pH}$ and NAE over time were significant in group $\mathrm{L}$ but not in group C (Figure 2). Mean urine ammonium concentrations were similar for both groups and did not change over time, with mean values remaining below $10 \mathrm{mmol} / \mathrm{L}$. Elevated urine ammonium concentrations were observed only when urine $\mathrm{pH}$ was below 6.30 . 


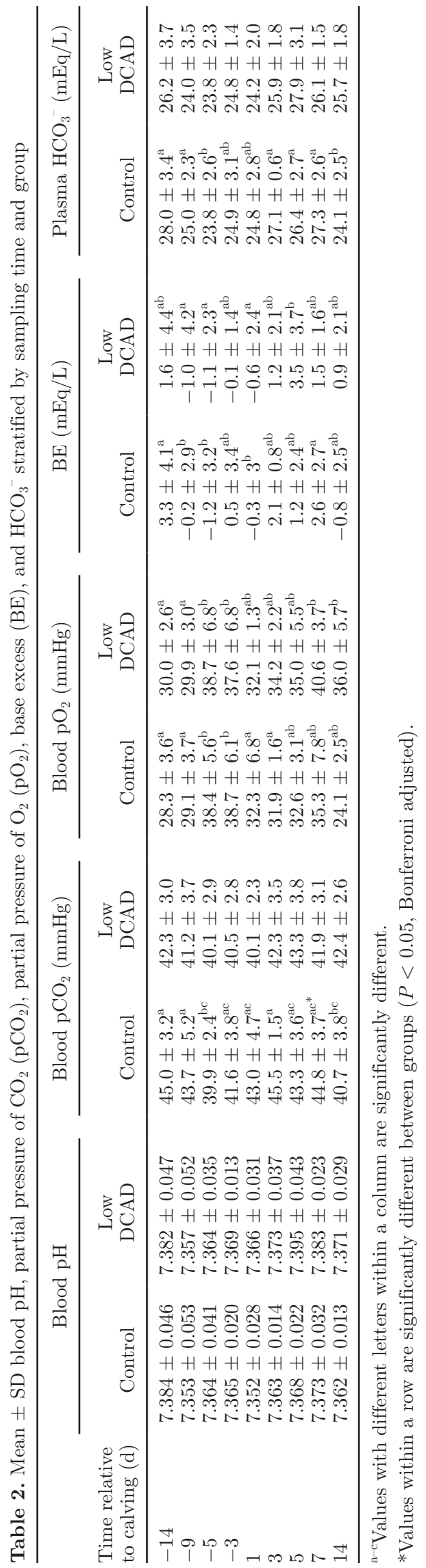

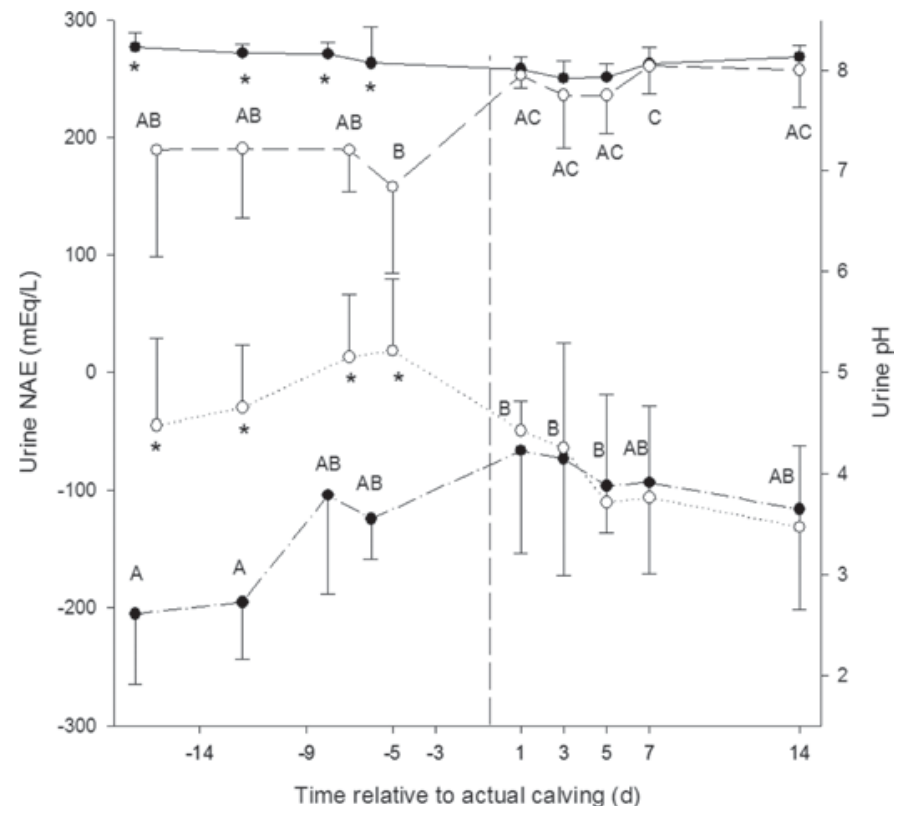

Figure 2. Mean $\pm \mathrm{SD}$ urine $\mathrm{pH}$ for group $\mathrm{C}$ (closed circles, solid line) and group L (open circles, dashed line) and urine net acid excretion (NAE) for group C (closed circles, dash-dotted line) and group L (open circles, dotted line). Twenty multiparous Holstein-Friesian dairy cows were assigned to 1 of 2 treatment groups and fed a low-DCAD ration $(\mathrm{DCAD}=-9 \mathrm{mEq} / 100 \mathrm{~g}$, group $\mathrm{L})$ or a control ration $(\mathrm{DCAD}=$ $+11 \mathrm{mEq} / 100 \mathrm{~g}$, group $\mathrm{C}$ ) for the last $3 \mathrm{wk}$ before the expected calving date. *Values are significantly different between groups $(P<0.05)$; time points with different letters within one group are significantly different $(P<0.05$, Bonferroni corrected $)$.

Regression analysis using only values obtained before calving, when cows in group L were on the low DCAD ration, revealed a negative linear association between daily feed intake and urinary NAE (adjusted $\mathrm{R}^{2}=$ $0.68, P=0.015)$, as well as negative linear associations between urinary NAE and BE (adjusted $\mathrm{R}^{2}=0.71$, $P=0.0097$ ), plasma $\left[\mathrm{HCO}_{3}{ }^{-}\right]$(adjusted $\mathrm{R}^{2}=0.72, P$ $=0.0095$ ), and blood $\mathrm{pCO}_{2}$ (adjusted $\mathrm{R}^{2}=0.72, P=$ 0.0092 ). The association between daily feed intake and urine $\mathrm{pH}$ before calving was not significant.

Regression analysis using all time points (obtained antepartum and postpartum) revealed that feed intake was negatively associated with NAE $\left(\mathrm{R}^{2}=0.33, P=\right.$ 0.028 ) and positively associated with urine $\mathrm{pH}$ (adjusted $\left.\mathrm{R}^{2}=0.40, P=0.0092\right)$.

\section{Plasma Biochemical Analysis}

Mean TP corrected plasma [Ca] on d 1 postpartum was lower than that determined at any other time point in both groups and was lower in group $\mathrm{C}$ than in group $\mathrm{L}$ (Figure 3). Three cows in group $\mathrm{C}$ and 2 cows in group L had protein-corrected plasma $[\mathrm{Ca}]$ below 8.0 $\mathrm{mg} / \mathrm{dL}$ on $\mathrm{d} 1$ postpartum 

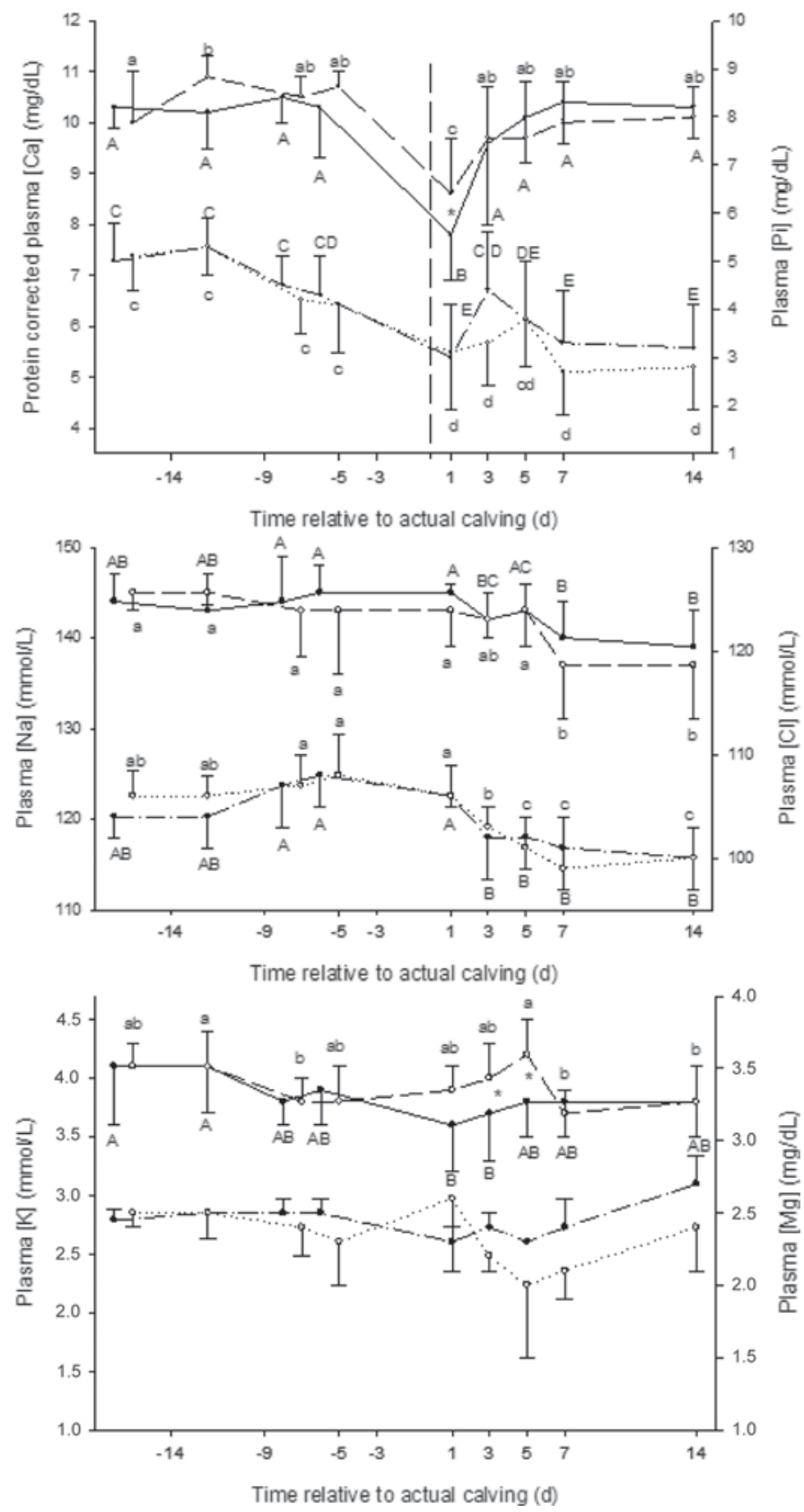

Figure 3. Mean \pm SD plasma Ca concentration corrected for plasma protein and plasma $\mathrm{Pi}$ concentration (upper panel), plasma $\mathrm{Na}$ and $\mathrm{Cl}$ concentration (middle panel), and plasma $\mathrm{K}$ and $\mathrm{Mg}$ concentration (lower panel). Plasma $\mathrm{Ca}, \mathrm{Na}$, and $\mathrm{K}$ concentration for group $\mathrm{C}$ are represented as solid lines with closed circles and for group L as dashed lines with open circles. Plasma $\mathrm{Pi}, \mathrm{Cl}$, and $\mathrm{Mg}$ concentration for group $\mathrm{C}$ are represented as dashed-dotted lines with closed circles and for group L as dotted lines with open circles. Twenty multiparous Holstein-Friesian dairy cows were assigned to 1 of 2 treatment groups and fed a low-DCAD ration $(\mathrm{DCAD}=-9 \mathrm{mEq} / 100 \mathrm{~g}$, group $\mathrm{L}$ ) or a control ration $(\mathrm{DCAD}=+11 \mathrm{mEq} / 100 \mathrm{~g}$, group $\mathrm{C}$ ) for the last $3 \mathrm{wk}$ before the expected calving date. Time points with different capital letters differ significantly within group C; time points with different lowercase letters differ significantly within group L. ${ }^{*}$ Values differ significantly between groups ( $P<0.05$, Bonferroni adjusted). The vertical dashed line marks parturition.
Mean plasma $[\mathrm{Pi}]$ decreased after calving in both groups and remained below mean preparturient values throughout the remainder of the study period. A treatment effect on plasma [Pi] was not identified (Figure $3)$. Regression analysis using values obtained before calving revealed that the plasma $[\mathrm{Pi}]$ was positively associated with the urine NAE (adjusted $\mathrm{R}^{2}=0.64, P$ $<0.0001$ ) and negatively associated with the urine $\mathrm{pH}$ (adjusted $\left.\mathrm{R}^{2}=0.54, P<0.0001\right)$. Regression analysis using all time points (obtained antepartum and postpartum) revealed a positive association of plasma [Pi] with NAE (adjusted $\mathrm{R}^{2}=0.32, P<0.0001$ ) and a negative associated with urine $\mathrm{pH}$ (adjusted $\mathrm{R}^{2}=0.42$, $P<0.0001)$.

Plasma concentrations of $\mathrm{Na}, \mathrm{K}, \mathrm{Cl}$, and $\mathrm{Mg}$ are presented in Figure 3. Mean plasma $[\mathrm{Na}]$ and $[\mathrm{Cl}]$ significantly decreased in both groups after calving with concentrations remaining below preparturient values until the end of the study period; a treatment effect was not identified for any these electrolytes.

Changes in mean plasma albumin ([alb]) and $[\mathrm{TP}]$ concentrations over time are presented in Figure 4. Significant time effects were observed for [alb] $(P<$ $0.0001)$, globulin $([$ glob] $)(P<0.0001)$ and $[\mathrm{TP}](P$ $=0.0002)$, with plasma [alb] being decreased from $\mathrm{d} 3$ postpartum until the end of the study in group L, but not in group C. Significant treatment effects as well as treatment $\times$ time interactions were present for [glob] and $[\mathrm{TP}]$. Decreases in plasma [glob] $(P<0.0001)$ and $[\mathrm{TP}](P=0.0005)$ were present in both groups from 14 $\mathrm{d}$ antepartum to $9 \mathrm{~d}$ antepartum, whereas a decrease in plasma [alb] was only apparent between d 1 and 3 postpartum $(P=0.0003)$. Treatment effects were determined for plasma [glob] $(P=0.019)$ and $[\mathrm{TP}](P$ $=0.027)$ but not for plasma [alb]. Plasma [glob] from $5 \mathrm{~d}$ postpartum until the end of the study period, and plasma $[\mathrm{TP}]$ from $3 \mathrm{~d}$ postpartum until the end of the study period, were lower in group L than in group C (Figure 4).

\section{Energy Metabolism}

A significant group effect for plasma [glucose], [NEFA], and $[\mathrm{BHBA}]$ was not present; however, all 3 indicators of metabolic status changed over time (Figure 5).

\section{Intravenous Glucose Tolerance Test}

Plasma glucose, IRI, and Pi concentrations during the IVGTT were determined in 6 cows selected at random from each group. Changes in the plasma concentrations of glucose, IRI, and Pi over time during the 3 IVGTT conducted antepartum 7 and $14 \mathrm{~d}$ postpartum are reported in Figure 6. 


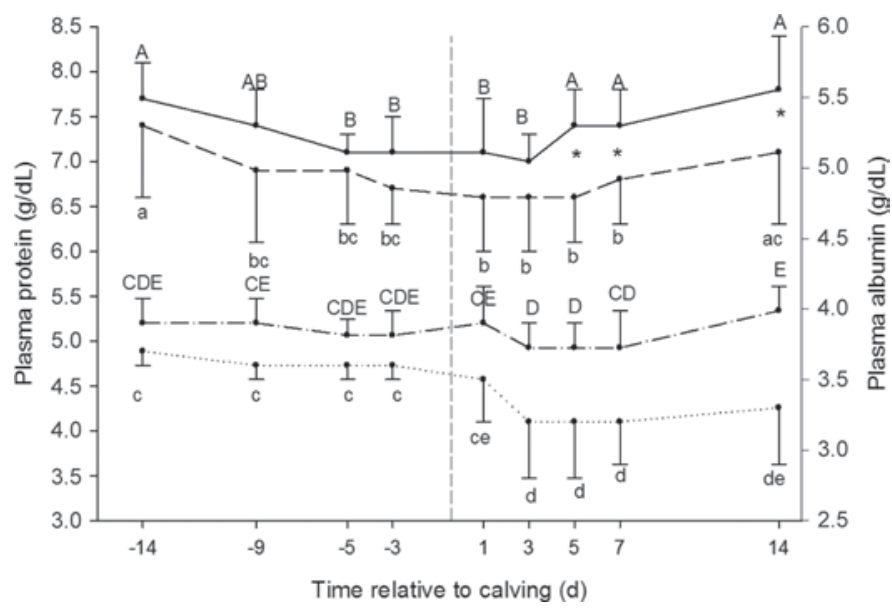

Figure 4. Mean \pm SD plasma total protein concentration for group $\mathrm{C}$ (solid line) and group L (dashed line) and mean \pm SD plasma albumin concentration at different time points for group C (dashed-dotted line) and group L (dotted line) over time. Time points with different letters differ significantly within groups. Twenty multiparous HolsteinFriesian dairy cows were assigned to 1 of 2 treatment groups and fed a low-DCAD ration $(\mathrm{DCAD}=-9 \mathrm{mEq} / 100 \mathrm{~g}$, group $\mathrm{L}$ ) or a control ration $(\mathrm{DCAD}=+11 \mathrm{mEq} / 100 \mathrm{~g}$, group $\mathrm{C}$ ) for the last $3 \mathrm{wk}$ before the expected calving date. ${ }^{*}$ Values are significantly different between groups $(P<0.05$, Bonferroni adjusted). The vertical dashed line indicates parturition. Time points with different letters within one group differ significantly $(P<0.05$, Bonferroni adjusted).

Mean area under the glucose concentration time curve from 0 to 120 min after intravenous dextrose infusion $\left(\mathrm{AUC}_{\text {gluc }}\right)$ and $\mathrm{T}_{50}$ following intravenous dextrose infusion were similar for both groups at all 3 IVGTT (Table 3). By contrast, basal [IRI], peak [IRI], and IRI increment after intravenous dextrose infusion were higher antepartum than on d 7 and 14 postpartum, with no difference between groups. The reciprocal of baseline [IRI] (1/IRI), the mean G/I ratio, the QUICKI and RQUICKI were higher and the $\mathrm{I} / \mathrm{G}$ ratio was lower in both groups after calving than before calving but a group effect was not identified. No difference between the values determined $7 \mathrm{~d}$ postpartum and $14 \mathrm{~d}$ postpartum were determined (Table 3 ).

The total amount of glucose excreted in urine in the $12 \mathrm{~h}$ following dextrose infusion in group $\mathrm{C}$ was $16.9 \pm$ $6.0 \mathrm{~g}, 5.1 \pm 6.6 \mathrm{~g}$ and $6.9 \pm 5.7 \mathrm{~g}$ antepartum and 7 and $14 \mathrm{~d}$ postpartum, respectively. This corresponds to an average $6.8,2.0$, and $2.8 \%$ of the administered glucose load for the respective treatment times. In group L, $10.8 \pm 4.9,10.6 \pm 14.2$, and $6.8 \pm 3.0 \mathrm{~g}$ of glucose were excreted in urine following dextrose infusion antepartum and 7 and $14 \mathrm{~d}$ postpartum, respectively. These amounts were equivalent to a mean $4.3 \%, 4.2 \%$ and $2.7 \%$ of the administered amount of dextrose on treatment times antepartum and $7 \mathrm{~d}$ and $14 \mathrm{~d}$ postpartum, respectively. Differences in the amount of glucose ex-
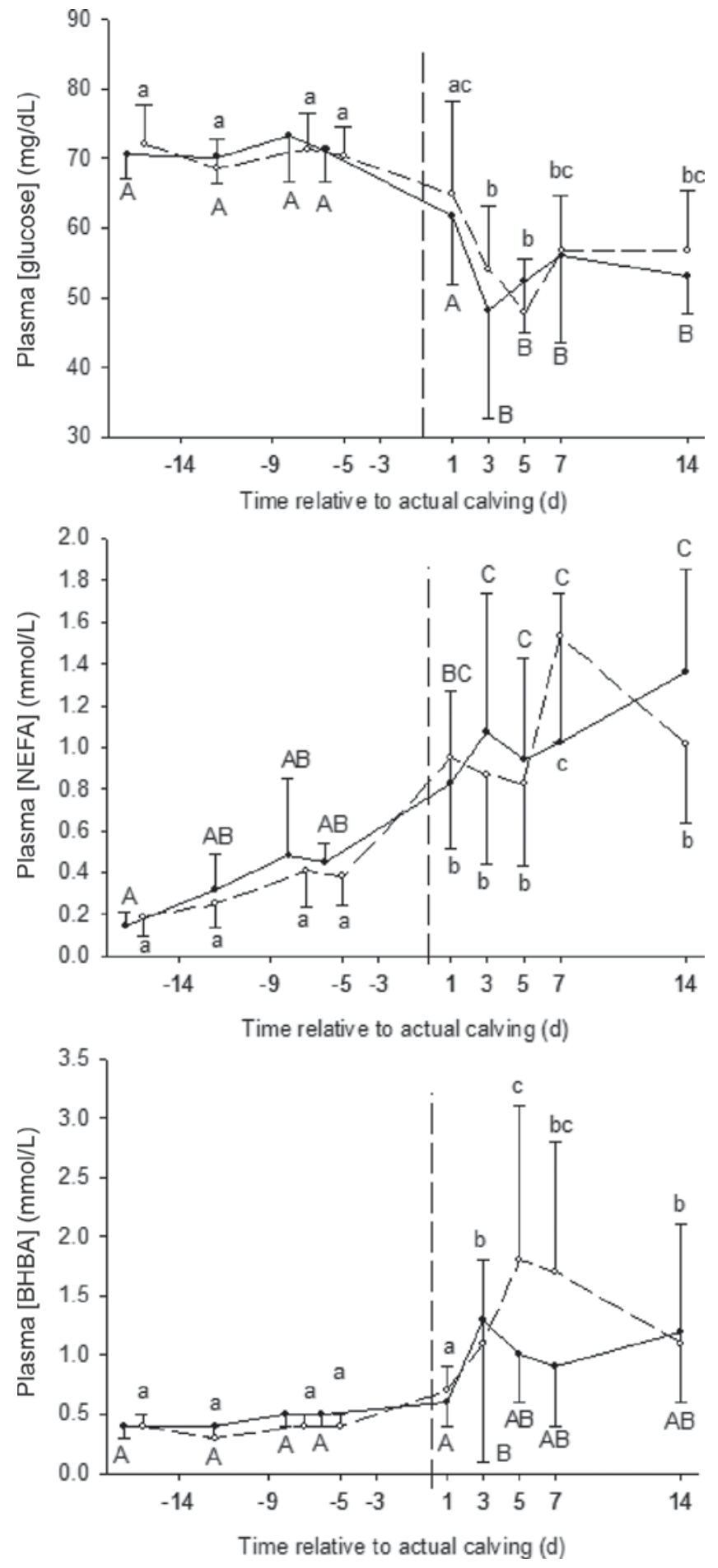

Figure 5. Mean \pm SD plasma glucose concentration (upper panel), plasma NEFA concentration (middle panel), and plasma BHBA concentration (lower panel) for group C (solid line, closed circles) and group L (dashed line, open circles). Time points with different letters differ significantly within groups $(P<0.05$, Bonferroni adjusted). The vertical dashed line marks parturition. Twenty multiparous HolsteinFriesian dairy cows were assigned to 1 of 2 treatment groups and fed a low-DCAD ration $(\mathrm{DCAD}=-9 \mathrm{mEq} / 100 \mathrm{~g}$, group $\mathrm{L}$ ) or a control ration $(\mathrm{DCAD}=+11 \mathrm{mEq} / 100 \mathrm{~g}$, group $\mathrm{C}$ ) for the last $3 \mathrm{wk}$ before the expected calving date. 

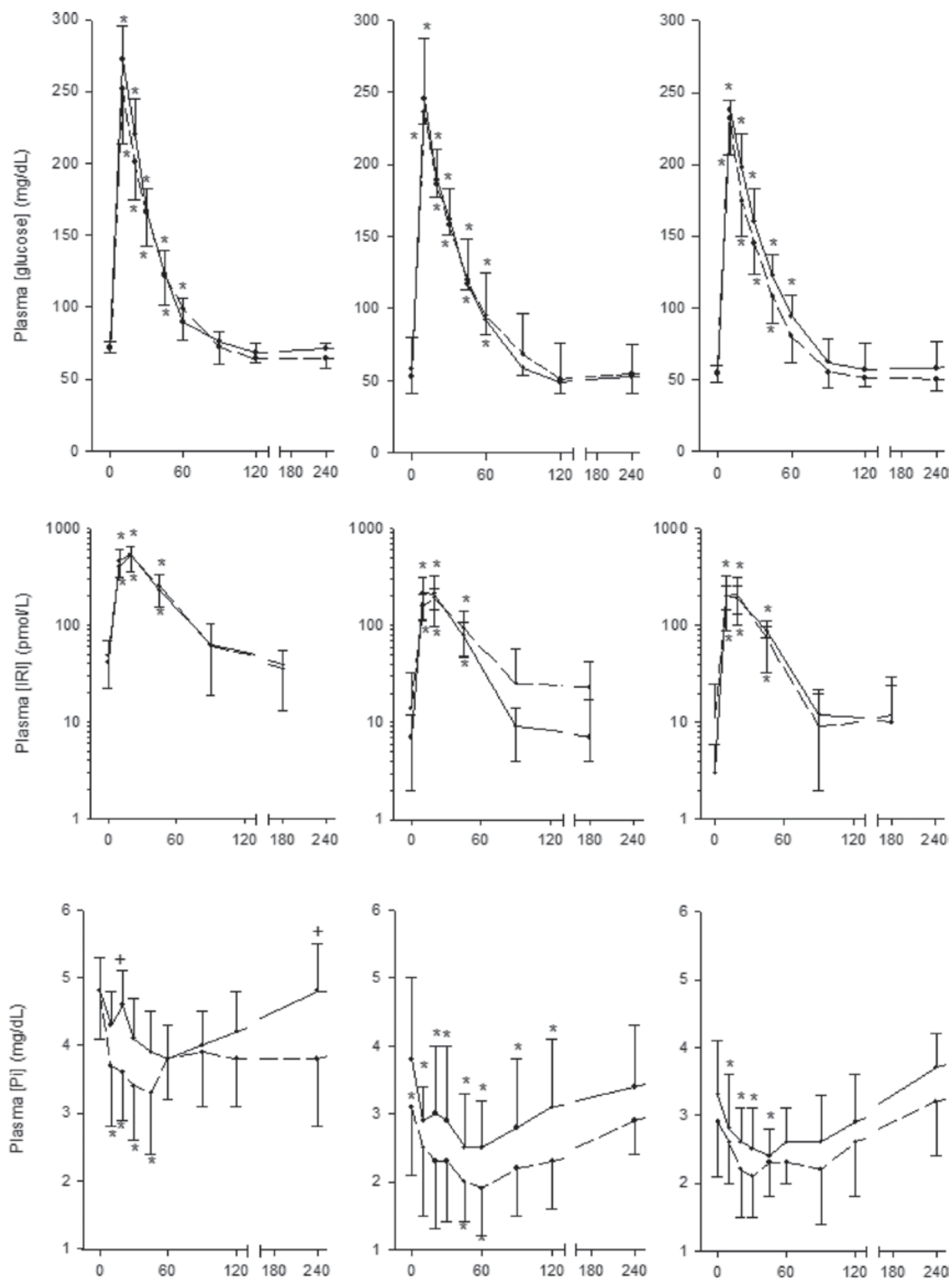

Time after start of dextrose infusion ( $\mathrm{min})$

Figure 6. Mean \pm SD plasma glucose concentrations (upper row), plasma immunoreactive insulin (IRI) concentrations (middle row), and plasma Pi concentration (lower row) during intravenous glucose tolerance test conducted antepartum (left column), on d 7 postpartum (middle column), and on d 14 postpartum (right column) in 6 randomly selected cows for group C (solid line) and group L (dashed line). Twenty multiparous Holstein-Friesian dairy cows were assigned to 1 of 2 treatment groups and fed a low-DCAD ration ( $\mathrm{DCAD}=-9 \mathrm{mEq} / 100 \mathrm{~g}$, group $\mathrm{L}$ ) or a control ration $(\mathrm{DCAD}=+11 \mathrm{mEq} / 100 \mathrm{~g}$, group $\mathrm{C})$ for the last $3 \mathrm{wk}$ before the expected calving date. $*$ Values within 1 group are significantly different from values determined at T0 (immediately before start of infusion, $P<0.05$, Bonferroni corrected). Values with + are significantly different between groups $(P<0.05)$. 
creted in urine between groups or over time were not significant.

The absolute decline in plasma $[\mathrm{Pi}]$ within $60 \mathrm{~min}$ after dextrose infusion was similar before and after calving and between groups (ranging from $1.1 \pm 0.4 \mathrm{mg} /$ $\mathrm{dL}$ to $1.4 \pm 0.6 \mathrm{mg} / \mathrm{dL}$ ). Plasma $[\mathrm{Pi}]$ was numerically higher in group $\mathrm{C}$ than group $\mathrm{L}$ on all 3 treatment days at baseline and in the $12 \mathrm{~h}$ following dextrose infusion but the group effect was not significant. Neither a group nor time effect on the decline of plasma [Pi] was significant. The $\mathrm{AUC}_{\mathrm{PI}-120}$ after dextrose infusion was lower on d $7(339.8 \pm 101.5 \mathrm{mg} \cdot \mathrm{min} / \mathrm{dL}$ and 251.4 $\pm 62.3 \mathrm{mg} \cdot \mathrm{min} / \mathrm{dL}$ in group $\mathrm{C}$ and $\mathrm{L}$, respectively) than antepartum $(451.8 \pm 76.8 \mathrm{mg} \cdot \mathrm{min} / \mathrm{dL}$ and 446.9 $\pm 82.9 \mathrm{~g} \cdot \mathrm{min} / \mathrm{dL}$ in group $\mathrm{C}$ and $\mathrm{L}$, respectively). No group differences were found on any of the treatment days.

Regression analysis using $\mathrm{V}_{\mathrm{d}}$ as an independent variable and [TP], [alb], and [glob] as dependent variables indicated a negative linear association between $\mathrm{V}_{\mathrm{d}}$ and plasma [alb] (adjusted $\mathrm{R}^{2}=0.39, P=0.020$ ) but not with [TP] or [glob]. This result indicated that a low albumin concentration was linearly associated with a larger $V_{d}$ for glucose, suggesting that the decrease in [alb] was due, in part, to extracellular fluid volume expansion.

\section{Urine Biochemical Analysis}

Spontaneously voided urine samples were obtained within $1 \mathrm{~h}$ of blood sampling from 12 cows on $\mathrm{d}-14$ (6 group C, 6 group L), 17 cows on d -9 (8 group C, 9 group L), 9 cows on d 1 (5 group C, 4 group L), 11 cows on d 3 ( 6 group $\mathrm{C}, 5$ group L), and 11 cows on d 5 relative to calving ( 6 group $\mathrm{C}, 5$ group L). Urine samples were obtained from all cows on the days $(-5$, $-3,7,14$ postpartum) where urine was collected volumetrically. The number of urine samples obtained at these time points (overall percentage, 60\%) was not different between groups at any time.

Cows in group $\mathrm{C}$ produced a mean urine volume of $11.9 \pm 1.6 \mathrm{~L}, 13.1 \pm 1.9 \mathrm{~L}, 21.2 \pm 4.1 \mathrm{~L}$ and $19.2 \pm 5.4$ $\mathrm{L}$ over $24 \mathrm{~h}$ following the sham-IVGTT antepartum, the IVGTT antepartum and the IVGTT on $\mathrm{d} 7 \mathrm{~d}$ and $14 \mathrm{~d}$ postpartum, respectively. In group L, measured urine volumes were $15.0 \pm 2.9 \mathrm{~L}, 13.2 \pm 2.5 \mathrm{~L}, 16.7$ $\pm 5.0 \mathrm{~L}$, and $17.9 \pm 5.7 \mathrm{~L}$ following the sham-IVGTT antepartum, and the IVGTT conducted antepartum, and on $7 \mathrm{~d}$ and $14 \mathrm{~d}$ postpartum, respectively. The volumes of urine produced over $24 \mathrm{~h}$ before and after parturition were different in group $\mathrm{C}(P=0.0063)$, but not in group L. No group effect on urine volume or the difference in urine volume after IVGTT antepartum and the sham-IVGTT antepartum was detected.

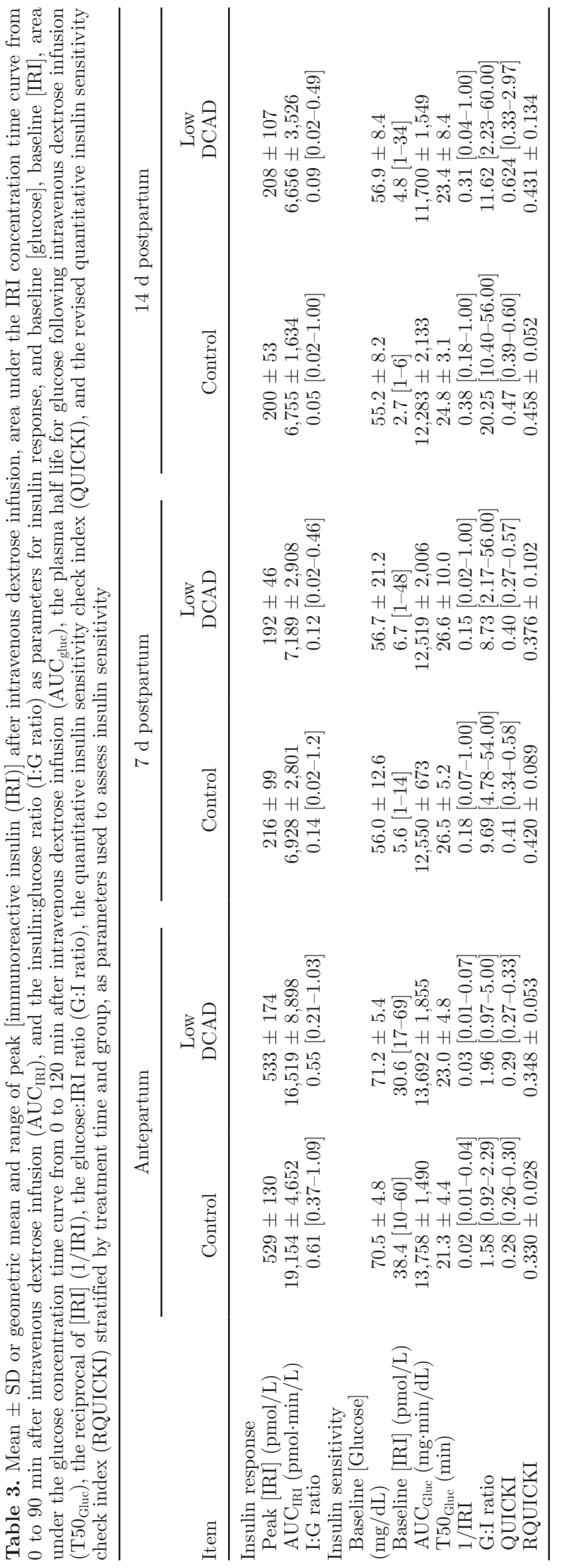

Journal of Dairy Science Vol. 94 No. 2, 2011 
Table 4. Mean $\pm \mathrm{SD}$ or geometric mean and range of urinary excretion of $\mathrm{Na}, \mathrm{K}, \mathrm{Ca}, \mathrm{Cl}, \mathrm{P}$, and $\mathrm{Mg}$ in grams per $24 \mathrm{~h}$ stratified by treatment, time, and group

Time (d) relative to calving

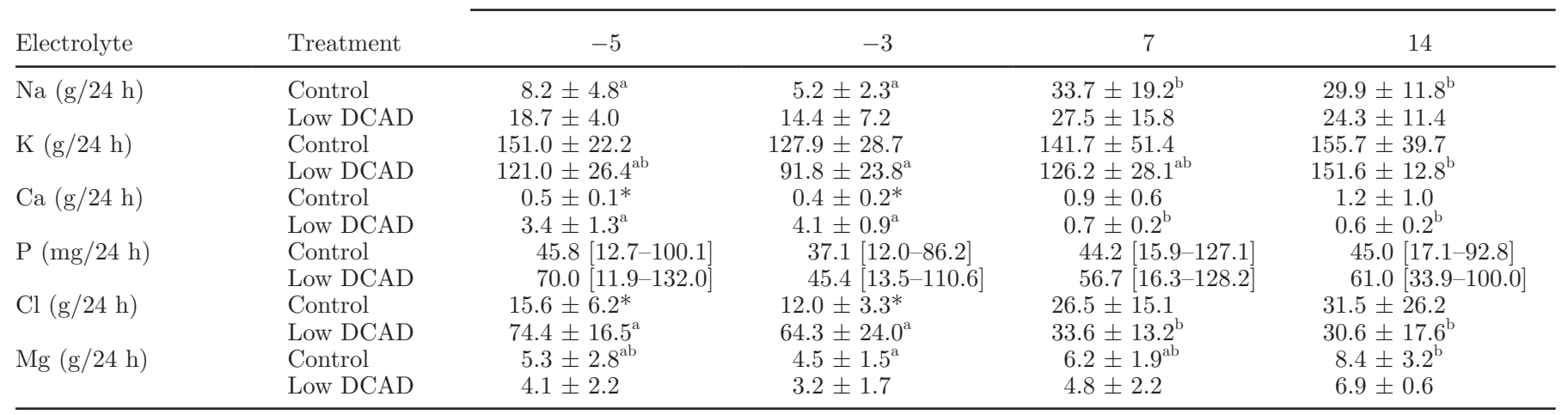

${ }^{\mathrm{a}, \mathrm{b}}$ Values with different letters within a row are significantly different.

*Values differ significantly between groups $(P<0.05$, Bonferroni adjusted).

The amount of $\mathrm{Na}, \mathrm{K}, \mathrm{Ca}, \mathrm{Pi}, \mathrm{Cl}$, and $\mathrm{Mg}$ excreted in urine over $24 \mathrm{~h}$ following dextrose infusion stratified by treatment and time is summarized in Table 4 . Whereas treatment effects on total urinary electrolyte excretion were observed for $\mathrm{Ca}$ and $\mathrm{Cl}$ before calving, with significantly higher amounts of $\mathrm{Ca}$ and $\mathrm{Cl}$ excreted in cows on the low-DCAD diet compared with control cows, significant time effects were observed for all analyzed parameters (Table 4). The amount of Ca excreted in urine over $24 \mathrm{~h}$ before calving was more than 6 -fold higher $(P<0.0001)$ in group $\mathrm{L}$ than group $\mathrm{C}$ and more than 4 times higher before than after calving $(P<$ 0.0001 ), indicating marked hypercalciuria in cows fed a low DCAD diet. Differences between sham-IVGTT antepartum and IVGTT antepartum in renal electrolyte excretion over $24 \mathrm{~h}$ were not observed. The amount of $\mathrm{P}$ excreted in the urine was very low but showed broad between-animal variability (Table 4). A group or time effect on $\mathrm{P}$ excretion was not identified.

Urine $\mathrm{pH}$ was related to urine NAE in a nonlinear manner (Figure 7, top panel). Multivariable regression analysis revealed a nonlinear positive association between urine $[\mathrm{Ca}] /[$ creatinine $]$ and NAE (adjusted $\mathrm{R}^{2}=$ $0.49, P=<0.0001$; Figure 7 , middle panel). Multivariable regression analysis also revealed a linear negative association with urine $[\mathrm{Ca}] /[$ creatinine $]$ and urine $\mathrm{pH}$ (adjusted $\mathrm{R}^{2}=0.67, P<0.0001$; Figure 7, bottom panel) whereby urine $[\mathrm{Ca}] /[$ creatinine $]=1.13-0.135 \times$ $\mathrm{pH}$. In other words, urinary calcium excretion increased nonlinearly with an increase in NAE and increased linearly with a decrease in urine $\mathrm{pH}$. Regression analyses revealed a linear association between urine $[\mathrm{Pi}]$ and NAE (adjusted $\mathrm{R}^{2}=0.67, P<0.0001$ ) and urine $[\mathrm{Pi}]$ and urinary $\mathrm{pH}$ (adjusted $\mathrm{R}^{2}=0.70, P<0.0001$ ).

\section{DISCUSSION}

The main objective of the study presented here was to explore potential effects of feeding a dry cow ration of moderately low DCAD on acid-base, calcium, and phosphorus homeostasis as well as glucose and protein metabolism during the periparturient period in highyielding dairy cows. Optimal target values for urine $\mathrm{pH}$ to decrease effectively the incidence of milk fever in dairy herds have not been identified, and recommendations for optimal urine $\mathrm{pH}$ vary widely (Horst et al., 1997; Roche et al., 2003; Charbonneau et al., 2006; Constable et al., 2009). A recent meta-analysis suggested that decreasing urine $\mathrm{pH}$ from 7.0 to 6.0 or lower led to a modest decrease in the incidence of milk fever but markedly increased the risk of decreased DMI in the prepartum period (Charbonneau et al., 2006). In the study presented here, cows ingesting a low DCAD ration had mean urine $\mathrm{pH}$ values of 7.2 and a 6 -fold increase in renal $\mathrm{Ca}$ excretion without affecting blood $\mathrm{pH}$ or plasma [Ca] before calving. This indicated that the DCAD diet in group L effectively challenged acidbase and calcium homeostasis and markedly increased calcium flux without overwhelming compensatory mechanisms or decreasing DMI.

Comparison of parameters in blood and urine characterizing acid-base homeostasis showed strong linear associations between urinary $\mathrm{NAE}$ and plasma $\left[\mathrm{HCO}_{3}{ }^{-}\right]$ and $\mathrm{BE}$; this finding is consistent with the consensus view that urinary NAE, and to a lesser extent urine $\mathrm{pH}$, are the most sensitive indicators of deregulations in acid-base homeostasis (Jørgensen, 1957; Kutas, 1965; Chan, 1972; Charbonneau et al., 2006; Hu et al., 2007; Constable et al., 2009). The nonlinear relationship 

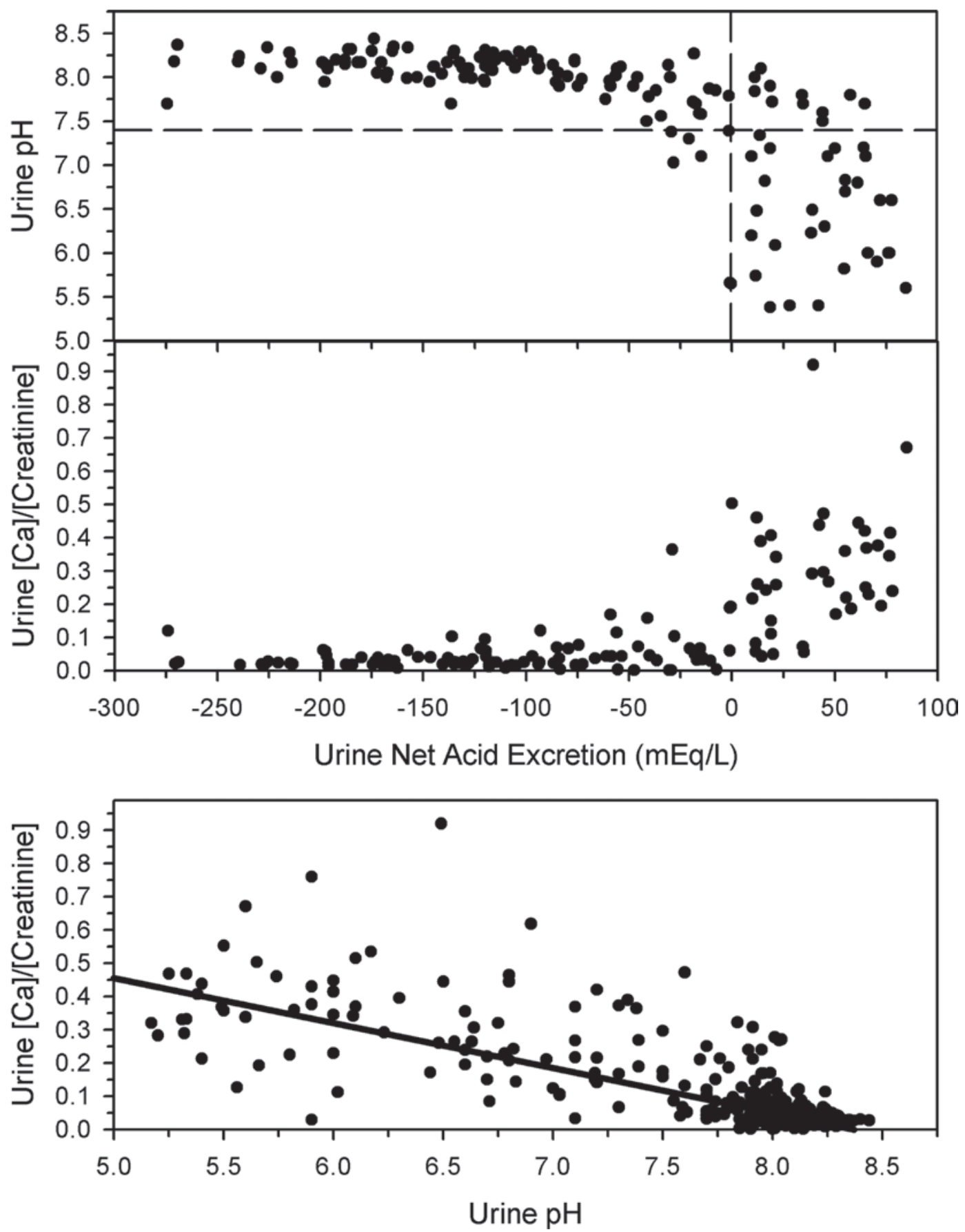

Figure 7. Relationship between urine $\mathrm{pH}$, net acid excretion (NAE), and ratio of urine calcium to creatinine concentration determined on urine samples obtained from dairy cows $(\mathrm{n}=20)$ between $14 \mathrm{~d}$ antepartum and $14 \mathrm{~d}$ postpartum. Cows were fed a low-DCAD diet $(\mathrm{n}=10)$ or a normal DCAD diet $(\mathrm{n}=10)$ antepartum. A nonlinear relationship exists between urine $\mathrm{pH}$ and $\mathrm{NAE}, \mathrm{such}$ that $\mathrm{pH}=\mathrm{a}+\log _{10}(-\mathrm{NAE}+$ b) (Constable et al., 2009). The dashed lines in the top panel indicate that urine NAE approximates zero when urine pH approximates 7.4. A nonlinear relationship also exists between urine $[\mathrm{Ca}] /[$ creatinine] and urine NAE (middle panel). In contrast, a linear relationship exists between urine $[\mathrm{Ca}] /[$ creatinine $]$ and urine $\mathrm{pH}($ bottom panel), whereby urine $[\mathrm{Ca}] /[$ creatinine $]=1.13-0.135 \times \mathrm{pH}$.

between $\mathrm{pH}$ and NAE in urine (Figure 7) is consistent with that recently determined for bovine urine, whereby urine $\mathrm{pH}=6.12+\log _{10}\left(-\mathrm{NAE}+\left[\mathrm{NH}_{4}{ }^{+}\right]+\right.$ 2.6) (Constable et al. 2009). In other words, changes in NAE reflect mild deregulations in acid-base homeosta- sis, whereas alterations in urine $\mathrm{pH}$ reflect more severe acidogenic effects.

The most likely reason that low-DCAD diets prevent periparturient hypocalcemia is that ingestion of lowDCAD diets increases Ca flux. The increase in Ca flux 
is due to an increase in the rate of Ca entry into the exchangeable $\mathrm{Ca}$ pool that approximates the rate of $\mathrm{Ca}$ exit from the exchangeable Ca pool (Vagg and Payne, 1970; Fredeen et al., 1988). Ingestion of a low DCAD diet increases $\mathrm{Ca}$ entry into the exchangeable $\mathrm{Ca}$ pool by 3 main mechanisms: enhanced intestinal absorption (Lomba et al., 1978; Schonewille et al., 1994; Roche et al., 2007), increased bone resorption (Block, 1984), and decreased bone accretion (van Mosel et al., 1994), with the latter 2 mechanisms appearing to be active only in the presence of acidemia and metabolic acidosis. Ingestion of a low DCAD diet also increases Ca exit from the exchangeable $\mathrm{Ca}$ pool by decreasing renal tubular Ca reabsorption (Stacy and Wilson, 1970; Fredeen et al., 1988), manifest as hypercalciuria. An increase in Ca flux allows the periparturient dairy cow to more readily cope with the marked perturbation in Ca homeostasis that occurs at the onset of lactation by shifting Ca exit from the exchangeable Ca pool from the kidney to the mammary gland. The net result is a marked reduction in urine calcium excretion and increased plasma total calcium concentration immediately after calving, as observed in this study (Table 4).

The results of plasma and urine biochemical analyses in our study indicated that ingestion of a low-DCAD diet did not affect the exchangeable $\mathrm{Ca}$ pool size, as characterized by the plasma Ca concentration, except for the first day postpartum, where TP-corrected plasma [Ca] was higher in group L than group C. This finding was consistent with results from other studies that acidogenic diets only affect plasma Ca concentration during times of marked disturbance in Ca homeostasis, such as at the onset of lactation (Vagnoni and Oetzel, 1998; Gasperlin et al., 2002; Ramos-Nieves et al., 2009). Ingestion of diets with more acidifying potential (lower DCAD than used in our study) appear to cause a greater increase in Ca flux before calving because such diets cause more than twice the amount of $\mathrm{Ca}$ to be excreted in urine than that observed in our study (Goff and Horst, 1998; Vagnoni and Oetzel, 1998; Moore et al., 2000). The proposed association between low-DCAD diets and increased $\mathrm{Ca}$ flux is supported by our finding that urine $\mathrm{Ca}$ concentration is positively associated with NAE in a nonlinear manner and negatively associated with urine $\mathrm{pH}$ in a linear manner (Figure 7), indicating that metabolic acidosis severe enough to decrease urine $\mathrm{pH}$ markedly is more effective in increasing $\mathrm{Ca}$ flux than milder metabolic acidosis that increases NAE with minor decreases in urine $\mathrm{pH}$ (Figure 7). Of considerable interest is that our finding of a nonlinear positive relationship between urine Ca excretion and NAE is remarkably similar to that observed in humans (Lemann et al., 2003), consistent with the presence of fundamental relationships between ingestion of an acidogenic diet and acid-base physiology and renal physiology. Assuming that increased Ca flux is the most important method for decreasing the incidence and severity of hypocalcemia at calving and that urine $\mathrm{Ca}$ concentration provides a clinically useful insight into Ca flux in the periparturient cow, it appears that measurement of urine Ca concentration will provide the best method for evaluating the risk of periparturient hypocalcemia. However, because of the linear negative association between urine $[\mathrm{Ca}] /[$ creatinine] and urine $\mathrm{pH}$ (Figure 7), measurement of urine $\mathrm{pH}$ provides a practical on farm method for evaluating calcium flux in cows before parturition.

An important finding of this study was that renal $\mathrm{Ca}$ loss decreased markedly in the low DCAD group from a mean $3.4 \mathrm{~g} / 24 \mathrm{~h}$ in late gestation to $0.7 \mathrm{~g} / 24 \mathrm{~h}$ after calving, whereas renal $\mathrm{Ca}$ excretion was not altered in cows on the control diet. The markedly higher daily renal Ca loss during late gestation in cows fed a low DCAD diet has been reported in other studies (Joyce et al., 1997; Vagnoni and Oetzel, 1998; Spanghero, 2002). Assuming an extracellular distribution volume for Ca of $176 \mathrm{~L}$ in a $675-\mathrm{kg}$ cow $(26 \%$ of the BW, Payne et al., 1967) the difference in renal Ca loss between ante- and postpartum in cows fed a low-DCAD diet of $2.7 \mathrm{~g} / \mathrm{d}$ provided a potential increase in mean extracellular total Ca concentration of approximately $1.5 \mathrm{mg} /$ $\mathrm{dL}$; this calculated value was slightly higher than the difference of $0.8 \mathrm{mg} / \mathrm{dL}$ observed in plasma total $\mathrm{Ca}$ concentration between the 2 groups on the day after calving (Figure 3).

Our results do not support the hypothesis that acidemia-induced increases in parathyroid hormone (PTH) receptor sensitivity, presumably by structural alteration of the receptor due to changes in $\mathrm{pH}$, play an important role in the mechanism by which ingestion of an acidogenic diet decreases the incidence and severity of periparturient hypocalcemia (Goff, 2008). We did not observe an effect of diet on blood $\mathrm{pH}$, yet plasma protein-corrected total calcium concentration was higher on the day after calving in cows consuming a low-DCAD diet, indicating that mechanisms other than decreased PTH receptor sensitivity were responsible.

Chronic acidemia and metabolic acidosis in humans results in negative phosphorus balance and a small decrease in serum phosphorus concentration due to increased urinary phosphorus loss (Lemann et al. 1966). Other studies investigating the effect of mild metabolic acidosis on phosphorus homeostasis in cows during late gestation suggest that mild to moderate acidemia and metabolic acidosis does not alter plasma [Pi] or Pi balance (Fredeen et al., 1988; Joyce et al., 1997; Gasperlin et al., 2002), although a weak association between decreasing plasma $[\mathrm{Pi}]$ and decreasing $\mathrm{DCAD}$ has been 
reported (Borucki Castro et al., 2004). These reports are in contrast with results of the study presented here where although a group effect on plasma [Pi] was not identified; the plasma [Pi] was found to be negatively associated with urine $\mathrm{pH}$ and positively associated with NAE in urine. Another recent study reported higher plasma $\mathrm{P}$ concentrations in the first week of lactation in cows fed a low-DCAD diet during late gestation (Ramos-Nieves et al., 2009). Our finding that urinary $[\mathrm{Pi}]$ was associated with urine $\mathrm{pH}$ and NAE is similar to findings in monogastric animals where $\mathrm{Pi}$ is an important buffer in urine and contributes considerably to the increase in urine titratable acidity during acidemia. A time effect on plasma [Pi] was identified; the small decrease in plasma $[\mathrm{Pi}]$ in late gestation paralleled the decrease in DMI, whereas the decrease in plasma [Pi] after calving was most likely due to the increased loss of $\mathrm{P}$ in milk.

In the present study the renal excretion of $\mathrm{Ca}$ and $\mathrm{Cl}$ in late gestation were higher in cows in group $\mathrm{L}$ compared with group C. Acidogenic diets have consistently produced a hypercalciuric effect through decreased renal reabsorption of filtered calcium (Lemann et al., 1966; Fredeen et al., 1988; Constable, 2007). A potential mechanism through which aciduria is likely to affect renal tubular $\mathrm{Ca}$ reabsorption is through altered expression of the epithelial $\mathrm{Ca}$ channel $\mathrm{ECaC} 1$ in the connecting tubule. The significant dependence of this $\mathrm{Ca}$ channel on luminal $\mathrm{pH}$ was demonstrated in vitro in rabbits whereby transcellular $\mathrm{Ca}$ transport was decreased by approximately $75 \%$ when luminal $\mathrm{pH}$ was decreased from 7.4 to 6.2 (Müller et al. 2001). The higher $\mathrm{Cl}$ content in the low DCAD ration is the probable cause for the higher renal $\mathrm{Cl}$ excretion in group $\mathrm{L}$, and the decrease in renal $\mathrm{Cl}$ excretion after calving in group L is likely caused by the difference in chloride content between the close-up ration and the ration fed during early lactation.

The major purpose of conducting IVGTT in cows on diets with low and high DCAD was to identify a possible effect of acidogenic diets on insulin responsiveness and sensitivity. Severe and moderate metabolic acidosis and acidemia decrease insulin responsiveness in humans and dogs (DeFronzo and Beckles, 1979; MacKler et al., 1951). Feeding an extremely low DCAD (-40.5 $\mathrm{mEq} / 100 \mathrm{~g})$ ration to nonlactating nonpregnant dairy cows induced acidemia (blood $\mathrm{pH}, 7.32$ ), metabolic acidosis (plasma $\left[\mathrm{HCO}_{3}{ }^{-}\right], 17.8 \mathrm{mmol} / \mathrm{L}$; urine $\mathrm{pH}, 5.4$ ), and decreased insulin responsiveness, as assessed by a lower peak [IRI] and higher peak plasma [glucose] in response to an IVGTT (Bigner et al., 1996). From the results of the study presented here, we conclude that feeding a DCAD diet that induces a mild fully compensated metabolic acidosis (blood $\mathrm{pH}$ and $\left[\mathrm{HCO}_{3}{ }^{-}\right]$within the reference range, urine $\mathrm{pH}$ approximately 7.2) does not affect the insulin response to an intravenous glucose load in dairy cows close to parturition, as a difference in by peak plasma [IRI], peak plasma [glucose], or I:G ratio between groups was not determined. Differences in insulin sensitivity between groups were assessed by comparing the baseline plasma [IRI], the reciprocal of baseline [IRI], the glucose/insulin ratio (G:I ratio), the QUICKI as well as the RQUCKI parameters that have been proposed as a surrogate indexes for insulin sensitivity (Katz et al., 2000; Perseghin et al., 2001; Holtenius and Holtenius, 2007; Muniyappa et al., 2008). A group effect was not observed for any of these indices. The differences in baseline plasma [glucose], [IRI], 1/IRI, G:I ratio, QUICKI, and RQUICKI, as well as $\mathrm{C}_{\max \text { IRI }}$ obtained before and after calving indicate that large changes in insulin responsiveness and tissue sensitivity to insulin occur around parturition in dairy cattle, which is in agreement with the results of earlier studies (Hart et al., 1978; Giesecke et al.,1987; Sano et al., 1993). An unchanged glucose disappearance curve, despite marked changes in insulin responsiveness, suggests large redundant capacity of the homeostatic mechanisms regulating the glucose homeostasis to compensate for the reduced insulin dependent glucose uptake. In dry cows shortly before calving, glucose clearance from plasma is achieved through glucose uptake by insulin responsive organs, glucose uptake by organs unresponsive to insulin (mainly the fetus), and by renal glucose excretion (Bell, 1995). A change in insulin-dependent glucose uptake must affect renal glucose excretion and fetal glucose uptake by the same proportion because neither is an active process (Stacey et al., 1978). The similar but numerically lower amounts of glucose excreted in urine in group L suggest that renal glucose excretion and thus probably fetal glucose uptake are not increased, implying that insulin-dependent glucose uptake might not be different between groups.

An insulin-dependent decline in the plasma $[\mathrm{Pi}]$ as a result of an intracellular shift following an intravenous glucose load has been reported in several species, including cattle (MacKler et al., 1951; Rasmussen et al., 1988; Grünberg et al., 2006), an effect that is likely due to an insulin dependent upregulation of $\mathrm{Na} / \mathrm{Pi}$ cotransporter gene expression ( $\mathrm{Li}$ et al., 1996). Therefore, in the study presented here, we elected to determine the hypophosphatemic effect of insulin as a tool to identify possible differences in tissue responsiveness to insulin between groups. Neither the plasma $[\mathrm{Pi}]$, the decline in plasma $[\mathrm{Pi}]$ following dextrose infusion, the $\mathrm{AUC}_{\mathrm{PI}}$ nor the amount of $\mathrm{Pi}$ excreted in urine was different between groups. These findings further imply that cows fed the low-DCAD diet were similarly sensitive to insulin as cows on the control diet. Differences in the $\mathrm{AUC}_{\mathrm{PI}}$ 
between before and after parturition are likely associated with the lower baseline plasma $[\mathrm{Pi}]$ after calving in both groups.

A potential concern of feeding acidogenic rations is that poor "palatability" of these supplements may affect DMI in late gestation and thereby exacerbate the negative energy balance that is present in all highyielding cows during early lactation, although it should be noted that feeding acidogenic rations antepartum can lead to increased postpartum feed intake (Joyce et al., 1997; Goff and Horst, 1998). Feed intake in the study presented here was numerically (but not significantly) lower in cows fed the low DCAD ration in the 2 wk before as well as in the 2 wk after calving. Even though a group effect on antepartum feed intake was not evident, multivariable regression analyses revealed a significant negative association between antepartum intake and urinary NAE on feed intake. A negative effect of low-DCAD diets on feed intake antepartum and postpartum has been reported in many studies and attributed to either poor palatability or deregulation of acid-base homeostasis (Oetzel and Barmore, 1993; Joyce et al., 1997; Vagnoni and Oetzel, 1998; Hu and Murphy, 2004; Ramos-Nieves et al., 2009). The negative effect of a low DCAD on feed intake antepartum was estimated in a meta-analysis to be around $11 \%$ for a DCAD reduction of $30 \mathrm{mEq} / 100 \mathrm{~g}$ (Charbonneau et al., 2006); however, Goff and Horst (1998) reported a positive effect on prepartum feed intake when dairy cows were fed a low DCAD ration during the last weeks of gestation. Positive effects of close-up diets low in DCAD on feed intake after calving have been reported in some (Joyce et al., 1997; Goff and Horst, 1998), but not all, studies (Moore et al., 2000; Ramos-Nieves et al. 2009). A positive effect of low-DCAD diets during the last weeks of gestation on feed intakes during early lactation may be due to improved $\mathrm{Ca}$ homeostasis and thus better motility of the gastrointestinal tract (Goff and Horst, 1998). Parameters reflecting energy balance, such as plasma NEFA or BHB concentration, did not reveal a significant group effect in our study. These results are in agreement with a recent study that was unable to identify negative effects on energy balance or liver triglyceride content in early lactating multiparous cows fed a low-DCAD ration during the close-up period (Ramos-Nieves et al., 2009). Deleterious effects of low-DCAD rations on the energy balance during early lactation have only been reported in heifers fed a closeup ration with low DCAD $(-15 \mathrm{mEq} / 100 \mathrm{~g}$, Moore et al., 2000).

Results of our study indicate that ingesting a lowDCAD ration before calving results in lower plasma albumin, globulin, and total protein concentrations af- ter calving. A marked periparturient decline in plasma total protein concentration in dairy cows is associated with the active translocation of immunoglobulins into the mammary gland during colostrogenesis (Larson and Kendall, 1957; McLennan and Willough, 1973). The results of a 1957 study indicated that the periparturient decline in plasma total protein concentration was largely due to a decreased globulin fraction whereas changes in plasma [alb] were marginal (Larson and Kendall, 1957). The results of a subsequent study in 1974 that used radiolabeled albumin suggested that plasma [alb] decreases rapidly postpartum as a result of decreased albumin synthesis in the liver and an increased extracellular fluid volume (Little, 1974); decreased albumin synthesis in early lactation can result, in part, from hepatic lipidosis as indicated by the strong correlation between serum [alb] and liver fat percentage $(\mathrm{r}=-0.80, P<0.001, \mathrm{n}=54$; Sevinc et al., 2003). The results of our study indicated that plasma [alb] was negatively associated with the apparent volume of distribution for glucose, indicating that part of the decrease in plasma [alb] was due to plasma volume expansion. As expected, the periparturient decrease in plasma total protein concentration was largely driven by a decrease in the globulin fraction. The decrease in plasma [globulin] was present before calving which is consistent with increased uptake of immunoglobulin $\mathrm{G}_{1}$ by the mammary gland, whereas the plasma [alb] decreased further after calving, when extracellular fluid volume increases in response to the demands of milk production (Larson and Kendall, 1957; McLennan and Willough, 1973) and liver fat percentage increases due to negative energy balance that is present in early lactation (Moore et al., 2000; Sevinc et al., 2003; Kessel et al., 2008).

An effect of ingesting a low-DCAD ration on plasma globulin concentrations in early-lactation dairy cows does not appear to have been reported previously. Chronic acidemia and metabolic acidosis decreases plasma protein concentration in humans and domestic animals by enhancing protein catabolism with a minimal increase in the rate of protein synthesis (Ballmer and Imoberdorf, 1995; Safránek et al., 2003). Nonetheless, we are hesitant to suggest that ingestion of a low-DCAD ration increases protein catabolism because studies in humans indicating that ingestion of an acidogenic diet perturbs protein metabolism and homeostasis report significant decreases in blood $\mathrm{pH}, \mathrm{BE}$, and bicarbonate concentration, suggesting that acidemia due to a partially uncompensated metabolic acidosis is needed to trigger this response (Boirie et al., 2000; Hannaford et al., 1982). Furthermore, acidemia-induced protein catabolism also has been reported to decrease plasma 
albumin synthesis (Ballmer et al., 1995), whereas our findings suggest that the plasma globulin fraction, but not the albumin fraction, was decreased by low-DCAD diet. On the other hand, when considering plasma globulins as the proinflammatory protein fraction, a lower plasma globulin concentration after calving in cows fed a low-DCAD diet during the close-up period could be indicative of a lower occurrence of inflammatory phenomena during early lactation in this group (Bertoni et al., 2008). The approximately $16 \%$ decline in plasma globulin concentration from d 14 antepartum to $1 \mathrm{~d}$ postpartum was similar in both groups suggesting that translocation of $\mathrm{IgG}_{1}$ into the mammary gland was similar for both groups but that the major difference was in the postparturient increase in plasma [glob]. The clinical relevance of this finding is not clear.

Despite standardized housing and feeding conditions, considerable interanimal variability was encountered for several parameters reflecting metabolic activity in these transition cows, including indices characterizing insulin responsiveness and sensitivity, urine $\mathrm{pH}$ and NAE, urine electrolyte excretion, and plasma NEFA and BHBA concentrations. Variability in the response to changing homeorhetic needs in dairy cows at the onset of lactation has been attributed to genetic factors (Kessel et al., 2008). These genetic factors are considered to strongly influence the individual metabolic activity potentially explaining the variability in the capacity to cope with metabolic stress in the transition period.

In conclusion, our results indicate that feeding a moderately acidogenic ration (DCAD, $-9 \mathrm{mEq} / 100$ $\mathrm{g}$ of $\mathrm{DM}$ ) to late gestation Holstein-Friesian cows decreased urine $\mathrm{pH}$ to approximately 7.0 to 7.2 , markedly increased Ca flux as assessed by increased urine Ca concentration, urine $[\mathrm{Ca}] /[$ creatinine $]$, and $24-\mathrm{h} \mathrm{Ca}$ excretion, and increased plasma $\mathrm{Ca}$ concentration on the day after calving, but did not affect insulin responsiveness and sensitivity. The effects of this moderately acidogenic diet on $\mathrm{P}$ homeostasis were small and unlikely to be of clinical relevance. A negative association between daily feed intake and urine NAE before calving was consistent with findings in other studies that low DCAD diets decrease feed intake before calving. Whereas parameters characterizing the energy balance of transition cows did not reveal a significant effect of diet, a low-DCAD diet was associated with a lower plasma total protein and globulin concentration after calving. Further investigation of the hypoproteinemic and hypoglobulinemic effect reported here is warranted because low-DCAD rations used in practice frequently target a urine $\mathrm{pH}$ of approximately 6.0 to 6.5 (Constable et al., 2009) and are therefore much more acidogenic than the ration tested in the present study.

\section{ACKNOWLEDGMENTS}

The authors thank the staff of the Purdue Dairy Center, Dept. of Animal Sciences, at Purdue University and E. Wieck from the Clinical Discovery Laboratory, School of Veterinary Medicine at Purdue University, for their valuable technical assistance.

\section{REFERENCES}

Ballmer, P. E., and R. Imoberdorf. 1995. Influence of acidosis on protein metabolism. Nutrition 11:462-468.

Ballmer, P. E., M. A. McNurlan, H. N. Hulter, S. E. Anderson, P. J. Garlick, and R. Krapf. 1995. Chronic metabolic-acidosis decreases albumin synthesis and induces negative nitrogen-balance in humans. J. Clin. Invest. 95:39-45.

Bell, A. W. 1995. Regulation of organic nutrient metabolism during transition from late pregnancy to early lactation. J. Anim. Sci. 73:2804-2819.

Bertoni, G., E. Trevisi, X. Han, and M. Bionaz. 2008. Effects of inflammatory conditions on liver activity in puerperium period and consequences for performance in dairy cows. J. Dairy Sci. 91:3300-3310.

Bigner, D. R., J. P. Goff, M. A. Faust, J. L. Burton, H. D. Tyler, and R. L. Horst. 1996. Acidosis effects on insulin response during glucose tolerance tests in jersey cows. J. Dairy Sci. 79:2182-2188.

Block, E. 1984. Manipulating dietary anions and cations for prepartum dairy cows to reduce incidence of milk fever. J. Dairy Sci. 67:2939-2948.

Blum, J. W., C. F. Ramberg Jr., K. G. Johnson, and D. S. Kronfeld. 1972. Calcium (ionized and total), magnesium, phosphorus and glucose in plasma from parturient cows. Am. J. Vet. Res. $33: 51-56$.

Boirie, Y., M. Broyer, M. F. Gagnadoux, P. Niaudet, and J. P. Bresson. 2000. Alterations of protein metabolism by metabolic acidosis in children with chronic renal failure. Kidney Int. 58:236-241.

Borucki Castro, S. I., L. E. Phillip, V. Girard, and T. Trembley. 2004. Altering dietary cation-anion difference in lactating dairy cows to reduce phosphorus excretion to the environment. J. Dairy Sci. 87:1751-1757.

Burnett, R. W., A. K. Covington, N. Fogh-Andersen, W. R. Kulpmann, and A. H. J. Maas. 1995. Approved IFCC recommendation on definitions of quantities and conventions related to blood gases and pH. Eur. J. Chem. Clin. Biochem. 33:399-404.

Chan, J. C. M. 1972. The rapid determination of urinary titratable acid and ammonium and evaluation of freezing as a method of preservation. Clin. Biochem. 5:94-98.

Charbonneau, E., D. Pellerin, and G. R. Oetzel. 2006. Impact of lowering dietary cation-anion difference in non-lactating dairy cows. J. Dairy Sci. 89:537-548.

Constable, P. D. 1999. Clinical assessment of acid-base status-Strong ion difference theory. Vet. Clin. North Am. Food Anim. Pract . 15:447-471.

Constable, P. D. 2007. Strong ion difference theory explains the relationship between urine $\mathrm{pH}$ and net base excretion in cattle. Pages 366-372 in Proc. 13th Int. Conf. Production Diseases in Farm Animals. M. Fürll, ed. Merkur Druck und Kopier, Leipzig, Germany.

Constable, P. D., C. C. Gelfert, M. Fürll, R. Staufenbiel, and H. Stämpfli. 2009. Application of strong ion difference theory to urine and the relationship between urine $\mathrm{pH}$ and net acid excretion in cattle. Am. J. Vet. Res. 70:915-925.

Constable, P. D., H. R. Staempfli, H. Navetat, J. Berchtold, and F. Schelcher. 2005. Use of a quantitative strong ion approach to determine the mechanism for acid-base abnormalities in sick calves with or without diarrhea. J. Vet. Intern. Med. 19:581-589.

DeFronzo, R. A., and A. D. Beckles. 1979. Glucose intolerance following chronic metabolic acidosis in man. Am. J. Physiol. 236:E328E334. 
Dishington, I. W. 1975. Prevention of milk fever (hypocalcemic paresis puerperalis) by dietary sat supplements. Acta Vet. Scand. 16:503-512.

Ender, F., I. W. Dishington, and A. Helgebostad. 1971. Calcium balance studies in dairy cows under experimental induction and prevention of hypocalcemic paresis puerperalis. Z. Tierphysiol. $28: 233-256$.

Fredeen, A. H., E. J. DePeters, and R. L. Baldwin. 1988. Effects of acid-base disturbances by differences in dietary fixed ion balance on kinetics of calcium-metabolism in ruminants with high calcium demand. J. Anim. Sci. 66:174-184.

Gasperlin, C., T. Zadnik, I. Jazbec, and J. Zust. 2002. Effects of dietary cation-anion difference on serum calcium, phosphorus and magnesium concentration in periparturient dairy cows. Slov. Vet. Res. 39:215-225.

Giesecke, D., M. Stangassinger, and W. Veitinger. 1987. Plasma-insulin und Insulinantwort bei Kühen mit hoher Milchleistung. Adv. Anim. Physiol. Anim. Nutr. 18:20-30.

Glantz, S. A., and B. K. Slinker. 1990. Primer of Applied Regression and Analysis of Variance. McGraw-Hill Book Co., New York, NY.

Goff, J. P. 2008. The monitoring, prevention, and treatment of milk fever and subclinical hypocalcemia in dairy cows. Vet. J. 176:50 57.

Goff, J. P., and R. L. Horst. 1998. Use of hydrochloric acid as source of anions for prevention of milk fever. J. Dairy Sci. 81:2874-2880.

Goff, J. P., and R. L. Horst. 2003. Role of acid-base physiology on the pathogenesis of parturient hypocalcemia (milk fever)-The DCAD theory in principal and practice. Acta Vet. Scand. Suppl. 97:51-56

Grünberg, W., D. E. Morin, J. K. Drackley, and P. D. Constable. 2006. Effect of rapid intravenous administration of $50 \%$ dextrose solution on phosphorus homeostasis in postparturient dairy cows. J. Vet. Intern. Med. 20:1471-1478.

Hannaford, M. C., L. A. Leiter, R. G. Josse, M. B. Goldstein, E. B. Marliss, and M. L. Halperin. 1982. Protein wasting due to acidosis of prolonged fasting. Am. J. Physiol. 243:E251-E256.

Hart, I. C., J. A. Bines, S. V. Morant, and J. L. Ridley. 1978. Endocrine control of energy metabolism in cow-Comparison of levels of hormones (prolactin, growth-hormone, insulin and thyroxine) and metabolites in plasma of high yielding and low yielding cattle at various stages of lactation. J. Endocrinol. 77:333-345.

Holtenius, P., and K. Holtenius. 2007. A model to estimate insulin sensitivity in dairy cows. Acta Vet. Scand. 49:29.

Horst, R. L., J. P. Goff, T. A. Reinhardt, and T. R. Buxton. 1997. Strategies for preventing milk fever in dairy cattle. J. Dairy Sci. $80: 1269-1280$

Hu, W., and M. R. Murphy. 2004. Dietary cation-anion difference effects on performance and acid-base status of lactating dairy cows: A meta-analysis. J. Dairy Sci. 87:2222-2229.

Hu, W., M. R. Murphy, P. Constable, and E. Block. 2007. Dietary cation-anion difference effects on performance and acid-base status of dairy cows post partum. J. Dairy Sci. 90:3367-3375.

Jørgensen, K. 1957. Titrimetric determination of the net excretion of acid/base in urine. Scand. J. Clin. Lab. Invest. 9:287-291.

Joyce, P. W., W. K. Sanchez, and G. P. Goff. 1997. Effect of anionic salts in prepartum diets based on alfalfa. J. Dairy Sci. 80:28662875.

Katz, A., S. S. Nambi, K. Mather, A. D. Baron, D. A. Follmann, G. Sullivan, and M. J. Quon. 2000. Quantitative insulin sensitivity check index: A simple, accurate method for assessing insulin sensitivity in humans. J. Clin. Endocrinol. Metab. 85:2402-2410.

Kessel, S., M. Stroehl, H. H. D. Meyer, S. Hiss, H. Sauerwein, F. J. Schwarz, and R. M. Bruckmaier. 2008. Individual variability in physiological adaptation to metabolic stress during early lactation in dairy cows kept under equal conditions. J. Anim. Sci. 86:2903-2912

Kutas, F. 1965. Determination of net acid-base excretion in the urine of cattle. Acta Vet. Acad. Sci. Hung. 15:147-153.

Larson, B. L., and K. A. Kendall. 1957. Changes in specific blood serum protein levels associated with parturition in the bovine. J. Dairy Sci. 40:659-666.
Lean, I. J., P. J. DeGaris, D. M. McNeil, and E. Block. 2006. Hypocalcemia in dairy cows: Meta-analysis and dietary cation anion difference theory revisited. J. Dairy Sci. 89:669-684.

Lemann, J., D. A. Bushinsky, and L. L. Hamm. 2003. Bone buffering of acid and base in humans. Am. J. Physiol. Renal Physiol. 285:F811-F832.

Lemann, J., J. R. Litzow, and E. J. Lennon. 1966. The effects of chronic acid loads in normal man: Further evidence for the participation of bone mineral in the defense against chronic metabolic acidosis. J. Clin. Invest. 45:1608-1614.

Li, H., P. Ren, M. Onwochei, R. J. Ruch, and Z. Xie. 1996. Regulation of rat $\mathrm{Na} / \mathrm{Pi}$ cotransporter-1 gene expression: The roles of glucose and insulin. Am. J. Physiol. 271:E1021-E1028.

Little, W. 1974. Effect of stage of lactation on concentration of albumin in serum of dairy cows. Res. Vet. Sci. 17:193-199.

Lomba, F., G. Chauvaux, E. Teller, I. Lengele, and V. Bienfet. 1978. Calcium digestibility in cows as influenced by excess of alkaline ions over stable acid ions in their diets. Br. J. Nutr. 39:425-429.

MacKler, B., H. Lichtenstein, and G. M. Guest. 1951. Effects of ammonium chloride acidosis on the action of insulin in dogs. Am. J. Physiol. 166:191-198.

McLennan, M. W., and R. A. Willough. 1973. Observation of serum protein values of cows during estrus, lactation and milk fever. Can. Vet. J. 14:233-242.

Moore, S. J., M. J. VanDeHaar, B. K. Sharma, T. E. Bilbeam, D. K. Beede, H. F. Buchholtz, J. S. Liesman, R. L. Horst, and J. P. Goff. 2000. Effects of altering dietary cation-anion difference on calcium and energy metabolism in peripartum cows. J. Dairy Sci. 83:2095-2104.

Müller, D., G. J. G. Hoenderop, C. H. Van Os, and R. J. M. Bindels. 2001. The epithelial calcium channel EcaC1: Molecular details of a novel player in renal calcium handling. Nephrol. Dial. Transplant. 16:1329-1335.

Muniyappa, R., S. Lee, H. Chen, and M. J. Quon. 2008. Current approaches for assessing insulin sensitivity and resistance in vivo: Advantages, limitations, and appropriate usage. Am. J. Physiol. Endocrinol. Metab. 294:E15-E26.

National Research Council. 2001. Nutrient Requirements of Dairy Cattle. 7th rev. ed. Nat. Acad. Sci., Washington, DC.

Oetzel, G. R., and J. A. Barmore. 1993. Intake of a concentrate mixture containing various anionic salts fed to pregnant, non-lactating dairy cows. J. Dairy Sci. 76:1617-1623.

Oetzel, G. R., J. D. Olson, C. R. Curtis, and M. J. Fettman. 1988 Ammoinium chloride and ammonium sulfate for prevention of parturient paresis in dairy cows. J. Dairy Sci. 71:3302-3309.

Payne, E., J. W. Ryley, and R. J. W. Gartner. 1967. Plasma, blood, and extracellular fluid volumes in grazing Hereford cattle. Res. Vet. Sci. 8:20-26.

Perseghin, G., A. Caumo, M. Caloni, G. Testolin, and L. Luzi. 2001. Incorporation of the fasting plasma FFA concentration into QUICKI improves its association with insulin sensibility in nonobese individuals. J. Clin. Endocrinol. Metab. 86:4776-4781.

Ramos-Nieves, J. M., B. J. Thering, M. R. Waldron, P. W. Jardon and T. R. Overton. 2009. Effects of anion supplementation to lowpotassium prepartum diets on macromineral status and performance of periparturient dairy cows. J. Dairy Sci. 92:5677-5691.

Rasmussen, A., H. H. Kinose, and I. Hessov. 1988. Severity of postoperative hypophosphatemia in relation to glucose administration and renal handling of phosphate. Acta Chir. Scand. 154:617-621.

Roche, J. R., D. E. Dalley, P. J. Moate, C. Grainger, M. Rath, and F. O'Mara. 2003. Detary cation-anion difference and the health and production of pasture-fed dairy cows. 2. Non-lactating periparturient cows. J. Dairy Sci. 86:979-987.

Roche, J. R., D. E. Dalley, and F. P. O'Mara. 2007. Effect of a metabolically created systemic acidosis on calcium homeostasis and the diurnal variation in urine $\mathrm{pH}$ in the non-lactating pregnant dairy cow. J. Dairy Res. 74:34-39.

Safránek, R., M. Holecek, J. Kadlcikova, L. Sprongl, C. Mislanova, M. Kukan, and J. Chladek. 2003. Effect of acute acidosis on protein and amino acid metabolism in rats. Clin. Nutr. 22:437-443. 
Sano, H., S. Narahara, T. Kondo, A. Takahashi, and Y. Terashima. 1993. Insulin responsiveness to glucose and tissue responsiveness to insulin during lactation in dairy cows. Domest. Anim. Endocrinol. 10:191-197.

Schonewille, J. Th., A. Th. Van't Klooster, A. Dirkzwager, and A. C. Beynen. 1994. Stimulatory effect of an anion (chloride)-rich ration on apparent calcium absorption in dairy cows. Livest. Prod. Sci. 40:233-240.

Seifi, H. A., M. Mohri, A. Ehsani, E. Hosseini, and M. Chamsaz. 2005. Interpretation of bovine serum total calcium: Effects of adjustment for albumin and total protein. Comp. Clin. Pathol. 14:155-159.

Sevinc, M., A. Basoglu, H. Guzelbektas, and M. Boydak. 2003. Lipid and lipoprotein levels in dairy cows with fatty liver. Turk. J. Vet. Anim. Sci. 27:295-299.

Spanghero, M. 2002. Urinary pH and mineral excretion of cows fed four different forages supplemented with increasing levels of an anionic compound feed. Anim. Feed Sci. Technol. 98:153-165.

Stacy, B. D., and B. W. Wilson. 1970. Acidosis and hypercalciuria: Renal mechanisms affecting calcium, magnesium and sodium excretion in the sheep. J. Physiol. 210:549-564.
Stacey, T. E., A. P. Weedon, C. Hanworth, R. H. T. Ward, and R. D. H. Boyd. 1978. Fetomaternal transfer of glucose analogs by sheep placenta. Am. J. Physiol. 234:E32-E37.

USDA. 2007a. Dairy 2007. Part I: Reference of dairy cattle health and management practices in the United States, 2007. USDA-APHISVS, CEAH, Fort Collins, CO.

USDA. 2007b. Dairy 2007. Part II: Changes in the U.S. dairy cattle industry, 1991-2007. USDA-APHIS-VS, CEAH, Fort Collins, CO.

Vagg, M. J., and J. M. Payne. 1970. The effect of ammonium chloride induced acidosis on calcium metabolism in ruminants. Br. Vet. J. 126:531-537.

Vagnoni, D. B., and G. R. Oetzel. 1998. Effects of dietary cationanion difference on the acid-base status of dry cows. J. Dairy Sci. 81:1643-1652.

van Mosel, M., H. S. Wouterse, and A. T. van't Klooster. 1994. Effects of reducing dietary $\left(\left[\mathrm{Na}^{+}+\mathrm{K}^{+}\right]-\left[\mathrm{Cl}^{-}+\mathrm{SO}_{4}{ }^{-}\right]\right)$on bone in dairy cows at parturition. Res. Vet. Sci. 56:270-276. 